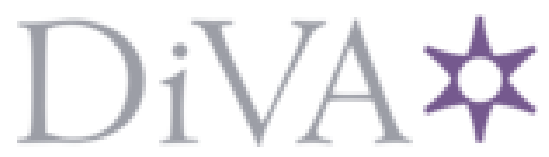

http://www.diva-portal.org

This is the published version of a paper published in Ecological Applications.

Citation for the original published paper (version of record):

Dynesius, M., Jansson, R., Johansson, M., Nilsson, C. (2004)

Intercontinental similarities in riparian-plant diversity and sensitivity to river regulation.

Ecological Applications, 14: 173-191

http://dx.doi.org/10.1890/02-5127

Access to the published version may require subscription.

N.B. When citing this work, cite the original published paper.

Permanent link to this version:

http://urn.kb.se/resolve?urn=urn:nbn:se:umu:diva-7892 


\title{
INTERCONTINENTAL SIMILARITIES IN RIPARIAN-PLANT DIVERSITY AND SENSITIVITY TO RIVER REGULATION
}

\author{
Mats Dynesius, ${ }^{1}$ Roland Jansson, ${ }^{1,3}$ Mats E. Johansson, ${ }^{1}$ And Christer Nilsson ${ }^{1,2}$ \\ ${ }^{1}$ Landscape Ecology Group, Department of Ecology and Environmental Science, Umeå University, \\ SE-901 87 Umeå, Sweden \\ ${ }^{2}$ Department of Natural and Environmental Sciences, Mid Sweden University, SE-851 70 Sundsvall, Sweden
}

\begin{abstract}
We asked whether assemblages of species with separate evolutionary histories differed in their response to similar human interventions. We assessed this by comparing the response of riparian plant communities to river regulation on two different continents. We compared free-flowing and regulated rivers between boreal parts of North America (Alberta and British Columbia) and Europe (Sweden), using a standardized sampling protocol and the same field staff on both continents. Although the two regions shared few species, both riparian plant-species diversity along free-flowing rivers and the response to different kinds of flow regulation were similar between the continents. The number of riparian-plant species and their amount of cover differed among types of water-level regime, but the continental affiliation of a river-margin site did not statistically explain any of the variation. Within continents, the local flora of the regulated river-margin sites was largely similar in species composition to the free-flowing ones, but the sites along storage reservoirs were more species-poor. The similarity in the response to regulation between the continents suggests that general guidelines for rehabilitation of degraded boreal rivers are a realistic goal.
\end{abstract}

The number of species and genera, plant cover, and species numbers in most trait groups (classified according to growth form and life span) were similar between free-flowing river margins in Europe and North America. Moreover, the regional native species pools of northern Sweden and Alberta were similar in size and composition of species groups, despite the fact that only $27 \%$ of the species in Alberta were found in northern Sweden. This is presumably because the floras share a common Tertiary origin and because the regions have had largely similar late-Tertiary and Quaternary histories. The most pronounced difference between the continents was that we found no exotic species on the 183 Swedish rivermargin sites, whereas $9 \%$ of the species found in all 24 North American plots taken together were exotics. All North American exotics found have occurred in Europe since prehistoric times, and the difference in exotic richness most likely reflects a difference in the number of species humans have transferred from one continent to another, rather than a difference in invasibility between the regions.

Key words: Alberta; British Columbia; community convergence; exotic plant species; hydroelectric development; river regulation; species-area relationship; species diversity, local and regional; species pool; Sweden; vascular plants.

\section{INTRODUCTION}

An important but neglected ecological issue is whether assemblages of species from different regions are differently sensitive to a specific human disturbance (Balmford 1996). Species vary in their vulnerability to current threats due to adaptations acquired or lost during the evolutionary history of their lineages. This potentially makes regional species pools with different histories differently resistant. Communities appear to be far more resistant and resilient to particular perturbations if their constituent species have faced similar challenges in the past (Balmford 1996, Danielsen 1997, Schmiegelow et al. 1997). Communities may also otherwise acquire characters that preadapt them to with-

Manuscript received 15 April 2002; revised 7 April 2003; accepted 8 April 2003. Corresponding Editor: G. A. Lamberti.

${ }^{3}$ Corresponding author: E-mail: roland@eg.umu.se stand human intervention (Dynesius and Jansson 2000). Thus, care should be taken not to generalize about responses to human disturbances among biogeographic regions, unless the sensitivity of their respective biota is considered. For example, the faunas and floras of oceanic islands have proved much more sensitive to invasions of exotics, compared to continental biota, resulting in numerous extinctions of island species (Brown and Lomolino 1998, Manne et al. 1999). Island faunas lacking indigenous predators have been more vulnerable to predator invasions, compared to islands where predators have always been present (Balmford 1996). Comparisons of mainland ecosystems between regions subject to similar human-induced disturbances have been virtually nonexistent (but see Danielsen 1997), despite the fact that humans are changing and transforming most ecosystems on Earth (Vitousek et al. 1997). 
Dams regulate the majority of the world's large river systems, for hydropower, irrigation, domestic water supply, and navigation (Petts 1984, Dynesius and Nilsson 1994). To provide a baseline for future rehabilitation efforts, knowledge is needed on how the biodiversity and ecosystem function of those rivers have been affected (Dynesius and Nilsson 1994, Naiman et al. 1995). In previous studies we have quantified the response of riparian vegetation to disturbance from hydroelectric exploitation of boreal rivers in northern Sweden, but whether these results apply to other regions is not known. In northern Sweden, riparian plantspecies richness and abundance are lower along both storage reservoirs and run-of-river impoundments compared to adjacent free-flowing rivers, while undammed reaches downstream of dams remain relatively species rich (Nilsson et al. 1991, Jansson et al. 2000). Riparian plant-species numbers in reservoirs and impoundments remain impoverished even $\sim 70$ yr after onset of regulation (Nilsson et al. 1997). Here, we compare the response of riparian-plant species diversity and composition to hydroelectric development between boreal parts of Alberta and British Columbia (North America) and northern Sweden (Europe). We chose this Canadian region to evaluate the generality of our results from northern Sweden because we wanted datasets to be as independent as possible (i.e., having minimum biogeographic overlap) while still being within the boreal zone.

To assess the effects of human disturbance, we compared regulated rivers with adjacent, free-flowing ones on both continents. For Swedish conditions, Jansson et al. (2000) concluded that adjacent free-flowing rivers could be used as proxies for preregulation conditions in the regulated rivers. We also compared riparian-plant communities along free-flowing rivers between the two continents. Local communities, such as the plant taxa occurring at a riparian site, are assembled from a regional pool of species available for colonization (Ricklefs 1987, Eriksson 1993, Zobel 1997). Most studies have shown that local diversity increases more or less linearly with regional diversity (e.g., Lawton 1999). This has been taken as evidence that local species richness is unsaturated, and not limited by local processes such as competition (Cornell 1985, Cornell and Lawton 1992, Schluter and Ricklefs 1993). Although a number of methodological issues have been raised against this conclusion (Srivastava 1999, Fox et al. 2000), the positive local/regional relationship does suggest that local and regional diversity cannot be understood in isolation. There are many examples of large variation in the sizes of regional species pools despite apparently similar environments, indicating strong historical effects: mangrove floras (Ricklefs and Latham 1993), temperate tree floras (Latham and Ricklefs 1993a) and mediterranean floras (Cowling et al. 1998), just to mention a few plant examples. Therefore, we also compared the regional pools of native plant species, as well as the relationships between local and regional diversity, between continents. By doing so, we attempt to assess whether or not local communities have converged or diverged in numbers and trait group composition of species (Cody and Mooney 1978, Orians and Paine 1983, Schluter and Ricklefs 1993, Westoby 1993). We define convergence as occurring if local communities are more similar (for example, in species richness) between regions than predicted from the regional species pools, and divergence as occurring if local communities are less similar than predicted from regional species pools.

The value of large-scale comparisons depends on how well the environments are matched (Orians 1987). Although the regions we studied differ somewhat, e.g., in bedrock composition (Hjelmqvist 1953, Kulling 1953, Ritchie 1987) and in the continentality of the climate (Hare and Thomas 1974, Raab and Vedin 1995), the studied rivers are all situated in the boreal coniferous zone, with a cold-temperate climate (Walter 1985), and have similar water level regimes (Anonymous 1979, 1987, 1989, Rosenberg 1986, Nilsson et al. 1993). Most comparisons made so far of local communities situated on different continents consist of compilations of data from various studies, each conducted with different aims and varying methodology. To minimize such differences we sampled all sites following a standardized sampling protocol by the same field staff in both boreal North America and boreal Europe. To our knowledge, this is the first intercontinental comparison made on the effects of a human intervention on species diversity and composition in a natural ecosystem, where all of the sites are sampled in the same way. Our aims were to test for differences between two biogeographically widely separated boreal regions (1) in the response of riparian-plant species diversity and cover to river regulation, and (2) in local, riparian floras along free-flowing rivers.

\section{Study Areas}

In North America, we investigated free-flowing and regulated river reaches in the headwaters of the North and South Saskatchewan Rivers of the Nelson River system, and in the upstream parts of the Peace and Athabasca Rivers of the Mackenzie River system. We chose 12 regulated river reaches. For each regulated reach, we also chose a matching reach in a free-flowing river, in the same river or a nearby one situated at a similar altitude and with similar discharge. Each reach was divided into six equally long sections, and we randomly chose one of the six sections, and located one study site in the middle of the section, giving a total of 12 free-flowing and 12 regulated sites (six sites downstream of dams, five in storage reservoirs, and one in a run-of-river impoundment). All study sites were situated in southwestern Alberta and in the Peace River catchment of central-eastern British Columbia, 
TABle 1. Geographic and climatic data for northern Sweden and Alberta, Canada.

\begin{tabular}{lcc}
\hline \hline \multicolumn{1}{c}{ Category } & Northern & \\
& Sweden & Alberta $\dagger$ \\
\hline Area $\left(\mathrm{km}^{2}\right)$ & 239443 & 617000 \\
Latitudinal extent $\left({ }^{\circ} \mathrm{N}\right)$ & $61^{\circ}-69^{\circ}$ & $51^{\circ}-60^{\circ}$ \\
Altitudinal extent $(\mathrm{m}$ above sea level $)$ & $0-2100$ & $<300-3700$ \\
Mean daily January temperature $\left({ }^{\circ} \mathrm{C}\right) \ddagger$ & $-6^{\circ}$ to $-16^{\circ}$ & $-10^{\circ}$ to $-22.5^{\circ}$ \\
Mean daily July temperature $\left({ }^{\circ} \mathrm{C}\right) \ddagger$ & $8^{\circ}-15^{\circ}$ & $12.5^{\circ}-17^{\circ}$ \\
Mean annual runoff $(\mathrm{mm}) \ddagger$ & $300-1400$ & $5-1500$ \\
\hline
\end{tabular}

$\dagger$ Study area excludes the prairie-dominated area $\left(\sim 44000 \mathrm{~km}^{2}\right)$ south of a line drawn from Mount Rae, near Calgary, and the point where the North Saskatchewan River crosses the province border.

¥ Data from Raab and Vedin (1995) for northern Sweden, and Hare and Thomas (1974) for Alberta.

Canada. There were 11 study sites in the Nelson River system, and 13 in the Mackenzie River system.

We compared the North American study sites with similar free-flowing and regulated river-margin sites in northern Sweden, sampled previously (Nilsson et al. 1989, 1991, 1997, Jansson et al. 2000). We used a total of 122 sites from four free-flowing rivers (Torne, Kalix, Pite, and Vindel Rivers), and 61 sites (8 sites downstream of dams and 53 in storage reservoirs) from seven regulated river systems (Lule, Skellefte, Ume, Ångerman, Indal, Ljusnan, and Ljungan Rivers). The population of study sites from Alberta and British Columbia are denoted "North American" and those from northern Sweden "European," not to imply that they are representative for boreal rivers in those entire areas, but to emphasize that they are situated on different continents.

The study sites in North America lie between latitudes $51^{\circ}$ and $56^{\circ} \mathrm{N}$. The upland vegetation along these

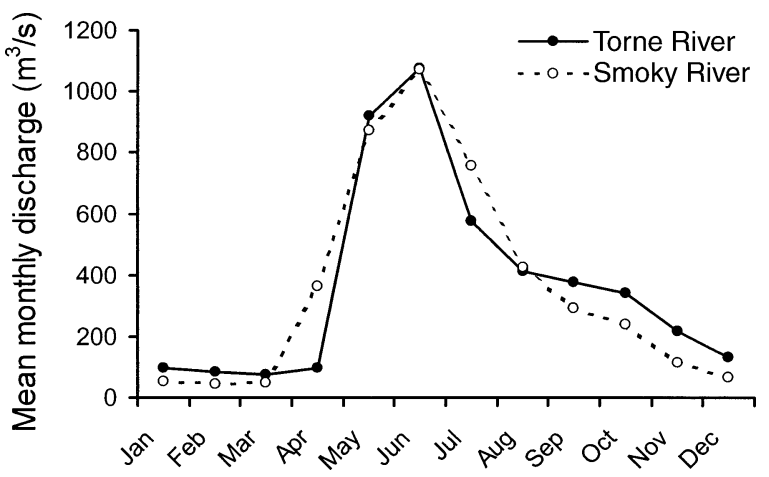

FIG. 1. Comparison of seasonal variation in water flow between two gauging stations along free-flowing rivers in northern Sweden (Kukkolankoski upper, Torne River, mean annual discharge $368 \mathrm{~m}^{3} / \mathrm{s}$, drainage area $34063 \mathrm{~km}^{2}$; Alberta, Waitino, Smoky River, mean annual discharge $364 \mathrm{~m}^{3} / \mathrm{s}$, drainage area $50300 \mathrm{~km}^{2}$ ). The stations were selected to have similar mean annual discharge, to allow comparing typical seasonal water flow variation between the study areas. Data from Kukkolankoski upper, Torne River $\left(65^{\circ} 35^{\prime} \mathrm{N}, 24^{\circ} 01^{\prime} \mathrm{E}\right)$ are from 1911 to 1975 (Anonymous 1995), and data from Waitino, Smoky River $\left(55^{\circ} 43^{\prime} \mathrm{N}, 117^{\circ} 37^{\prime} \mathrm{W}\right)$ are from 1915 to 1986 (Anonymous 1987). studied river sections ranges from montane coniferous forest dominated by Pinus contorta, Picea glauca, and $P$. engelmanni, to forests dominated by Populus tremuloides and Picea engelmanni on lower elevations (Moss 1983, Ritchie 1987). The study sites in Europe lie between latitudes $61^{\circ}$ and $68^{\circ} \mathrm{N}$. Here, the upland vegetation along the rivers ranges from subalpine birch forests dominated by Betula pubescens ssp. tortuosa, to coniferous forests dominated by Pinus sylvestris and Picea abies. Mean runoff, as well as daily temperatures during January and July, are similar between the continents for most of the study areas, although parts of the North American study area have a more continental climate, with warmer summers, colder winters, and less runoff (Table 1). The coordinates of the North American and European study sites are given in appendices to this paper in the Ecological Archives.

The North American rivers flow from the eastern slope of the Rocky Mountains (the Cordillera), to the Interior Plains with bedrock composed of Cretaceous sedimentary shales, siltstones, and sandstones (Ritchie 1987). The proportion of alkaline bedrock is high. On the Interior Plains, tills from the last glaciation overlay older tills, forming thick deposits together with extensive glacio-lacustrine sediments (Ritchie 1987). The European rivers flow from the Scandinavian mountain range through a monadnock plain, to undulating hilly land, flattening out into a narrow coastal plain (Rudberg 1970). Soils are dominated by glacial tills, until the rivers start to cut into sandy-silty sediments 90-200 $\mathrm{km}$ from the coast. The bedrock of the Scandinavian mountain range is complex and partly composed of amphibolites, schists, and sparagmites (Kulling 1953). The remaining area consists of the Baltic shield of Precambrian origin with acidic bedrock predominantly composed of granite and gneiss (Hjelmqvist 1953).

In the free-flowing boreal rivers on both continents, seasonal water level fluctuations are large, with the highest levels attained during spring floods due to snowmelt (Fig. 1; Rosenberg 1986, Nilsson et al. 1993). During some years, ice jams may raise floodwater levels farther in the northernmost rivers. Water levels then recede during the growing season (Fig. 1). Develop- 
ment of boreal rivers for hydropower production has resulted in the replacement of natural flow regimes with four main regulated water level regimes. First, in the high-capacity storage reservoirs of the upper reaches, the water level is at its lowest in spring and is then raised to reach its maximum in late summer. Second, in the low-capacity, run-of-river impoundments that provide water to hydropower stations, the water level fluctuates daily or weekly between its statutory high and low levels (in most cases $0.5-1 \mathrm{~m}$ stage change) throughout the year. Third, there are reaches that are not impounded by a dam downstream, but where upstream dams affect flow. These reaches maintain their annual discharge, but water level fluctuations are often reduced in height, although in many cases with a largely natural rhythm. Fourth, in some sections of the rivers, sometimes several kilometers long, the river channel is dry or has very low discharge because of underground passage of water through tunnels and hydroelectric power stations.

Although the main water level regimes are similar between the continents, the rivers differ in the configuration of dams, reservoirs, and power stations. The studied North American regulated rivers are characterized by long, unimpounded reaches downstream of dams, but such reaches are uncommon in the studied European rivers. Here, run-of-river impoundments are consecutive along the middle and lower main-river channels; tailwater reaches are scarce or absent. In Sweden, the studied rivers are regulated for hydropower, whereas river regulations in Alberta are also for irrigation.

\section{Methods}

To ensure that most riparian species present along a reach were sampled, including the many rare ones, each study site spanned a $200 \mathrm{~m}$ long strip of river margin on one side of the river. We usually sampled the northern, south-facing side, unless it was difficult to access due to absence of roads (six sites in North America, and three sites in Europe). In the free-flowing rivers, each site spanned the entire area between the spring flood high, i.e., the highest level attained at least once every two years, and summer low levels. Water level variations are quite similar among years. For example, the coefficient of variation of peak discharge in the free-flowing lower Vindel River (northern Sweden) 1961-1990 was 23\%, indicating that high-water levels are consistent among years. In most cases, the spring high-water level was judged equivalent to the lower end of continuous occurrences of flood intolerant species such as Vaccinium myrtillus. Deposition of water transported drift material, and erosion of sediment and organic matter also helped determining the high-water level. Upland vegetation is generally species poor compared to riparian zones, making the exact delimitation of the riparian zone less critical. In the regulated rivers, we sampled a $200 \mathrm{~m}$ long area between the damming and summer drawdown levels. The damming levels vary little among years, and were identified in the same way as the high-water level in the free-flowing rivers (i.e., the level attained at least once every two years). The level of summer drawdown was judged from water level data, aided by identifying the lower end of scouring from wave action.

At each site we recorded the presence of all vascular plant species, irrespective of their size or life stage, by thoroughly searching through the entire 200-m strip between the high and low water levels. To minimize error, two persons analyzed each site independently and results were combined (Nilsson 1992). Inventorying long strips of riparian zone (100 to $500 \mathrm{~m}$ long) is the standard methodology in studies of species richness patterns of shoreline vegetation (e.g., Nilsson et al. 1989, 1991, 1997, Hill and Keddy 1992, Décamps and Tabacchi 1994, Planty-Tabacchi et al. 1996), because most riparian-plant species are relatively rare and are likely to be unrecorded if many small fixed-area plots were sampled at each site. The area needed to record most species present locally depends on successional stage, the spatial heterogeneity of the riparian zones, and the size of the species pool. Species accumulation curves from northern Sweden showed that $200 \mathrm{~m}$ long strips of river margin were sufficient to record most species. Few additional species were recorded by sampling more area (R. Jansson, unpublished data). Each site was visited only once. The North American sites were visited in August 1992, and the European ones during July and August 1988-1993, except for a few in the regulated Ume River that were visited in late June. In these study areas, it is possible to record nearly all species present by a single visit in late summer, since the flora is largely dominated by perennial species and since the short growing season lacks a spring aspect with early-developing plants that are absent later in the season (M. Dynesius, R. Jansson, M. E. Johansson, and C. Nilsson, personal observations).

At each site, we also recorded the percentage cover of herbs + dwarf shrubs (woody individuals $<0.25 \mathrm{~m}$ high) and trees + shrubs $(>0.25 \mathrm{~m}$ high), width and height of the river margin, substrate fineness, substrate heterogeneity, and the exposure to wave and flow action. The percentage covers of the two vegetation layers were estimated by eye independently by two persons; final cover values were reached by consensus. Of course, this method only gives rough estimates. We measured bank width at $0,50,100,150$ and $200 \mathrm{~m}$ as the horizontal distance between the highest and lowest water levels attained during the growing season. Bank height was measured as the vertical distance between these two levels, using a rod and level. Bank area was calculated as the length $(200 \mathrm{~m})$ multiplied by the average width. We determined percentage cover of the following substrate types by eye: peat, clay, silt, sand, gravel, pebbles, cobbles, boulders, and bedrock. Substrate fineness was calculated according to Nilsson et 
al. (1989) by assigning values to each substrate class, going from -9 for boulders, to +9 for clay, and then calculating a mean of those values by weighing the value for each substrate class by its percentage composition of the riverbank substrate. Peat and bedrock were arbitrarily assigned the values +12 and -12 , placing them marginal to clay and boulders, respectively. This ranked substrates in terms of water-holding capacity from high to low. Substrate heterogeneity was defined as the number of substrate types per site. We estimated the scouring from waves and current by ranking river stretches using a four-level qualitative scale: (1) pools and river lakes with sheltered shores, (2) slow-flowing stretches and river lakes with weakly wave-exposed shores, (3) runs, and river lakes with moderately exposed shores, and (4) riffles, and river lakes with strongly exposed shores. Wave exposure was estimated by the length of the fetch. When a site included two or more categories, values were weighed by the percentage of each type. The nomenclature and taxonomy of species follow Mossberg et al. (1992) and Moss (1983), although some taxa were treated collectively because they belong to apomictic species complexes, or because they were difficult to identify. If we found that two species on the two continents were treated as conspecific by some authority after checking in Moss (1983), Mossberg et al. (1992), or Krok and Almquist (1994), we treated them as one taxon. For full information on taxonomy and nomenclature, see appendices to this paper in the Ecological Archives. Voucher specimens are deposited in the UME herbarium at Umeå University, Sweden.

\section{Data analysis}

Plant classifications.-We classified all species after growth form into forbs + ferns + club mosses (including Selaginellaceae) + horsetails; graminoids (i.e., Poaceae, Cyperaceae, and Juncaceae); and woody species. We also classified all species as being evergreen or not, following Mossberg et al. (1992) and Moss (1983). The woody species were further divided into tree species (maximum height $>5 \mathrm{~m}$ ) vs. shrubs and dwarf shrub species (maximum height $<5 \mathrm{~m}$ ). Data on plant height were taken from Moss (1983) and Mossberg et al. (1992). Moreover, all species were classified after life span into perennial species vs. annual + biennial species (following Lid [1987] and Moss [1983]), and after their geographic origin into native species or exotic species (i.e., introduced from another continent). A few species that may be both biennial and perennial were classified as annual + biennial.

Comparability of riparian zones between the continents.-Since our aim was to compare patterns in species richness and composition between the continents, we wanted to know whether there were differences in the riparian environments that would lead to differences in riparian species richness per site between the regions. Therefore, we performed a stepwise multiple regression analysis of the relationship between the number of plant species per riparian site and the environmental variables sampled for the European sites along free-flowing rivers (122 sites). The predictor variables were area, exposure to wave and flow action, and substrate heterogeneity and fineness. Since a plot of species richness vs. substrate fineness indicated a hump-shaped relationship, we also included the square of substrate fineness as a predictor variable. Area was $\log _{10}$-transformed prior to analysis to make the relationship with species richness linear. Then we used the regression model obtained to calculate the predicted species richness per site for the North American sites along free-flowing river reaches (12 sites), and compared the mean of those predicted values with the observed species richness for sites on both continents. The more similar these values, the less reason to expect that differences in these environmental variables cause differences in species richness between the study sites on the two continents, under the null hypothesis that the assemblages of species respond similarly to environmental variation.

Riparian zones along free-flowing rivers.-We tested for differences between the continents in riparian-plant taxon richness along free-flowing rivers. We compared the mean number of species, genera, and families (both including and excluding exotics) per site between $\mathrm{Eu}-$ rope and North America, using two-tailed $t$ tests. The taxonomy for genera and families follows Krok and Almquist (1994) and Moss (1983), since their treatment of genera and families is very similar. We also tested for differences in the number of species per site in the different groups of species defined above, and in the vegetation cover, using two-tailed $t$ tests. We also calculated the mean similarity (Jaccard's index) per site in the composition of species, genera, and families between the free-flowing sites within and between the continents. Jaccard's index is the ratio of species found in both samples to the total number of species found in either of the samples. Jaccard's index is sensitive to differences in species richness between samples, but is suitable here, since such differences were small.

For each region, we estimated the proportion of the species in the regional native plant species pool (see next section) that were found on any of the river-margin sites along free-flowing rivers. As a simple measure of the overlap between the riparian flora of one region and the total regional flora of the other, we counted the proportion of species, genera, and families found on all the riparian sites along free-flowing rivers combined in one region, that were present in the regional native species pool of the other.

Native plant species pools.-Whether or not local species numbers have converged can only be evaluated in relation to the regional assemblage of species from which the species occurring locally are drawn (Schluter and Ricklefs 1993). The size of the species pool available for colonization of a local site is dependent on the 
colonization ability and habitat requirements of species, and thus dependent on scale in both space and time (Eriksson 1993, Zobel 1997). The propagules arriving at a specific site are likely to be composed of more species drawn from an increasingly larger area the longer the time frame considered. We addressed the problem of spatial scale by calculating species-area curves of the form

$$
\log S=z \times \log A+\log c
$$

where $S$ is the number of species, $A$ the area, and $z$ and $c$ are constants, for both northern Sweden and Alberta, spanning areas from a few square meters of riparian land to the entire region. All riparian sites included in these analyses were from free-flowing rivers. Then, we tested whether the species-area relationship differed between the continents using univariate analysis of covariance (ANCOVA) of species richness with area as a covariate and continent as a factor. We tested for differences in the species-area relationship between the continents for native species, tree species, and shrub and dwarf shrub species.

We constructed the species-area curve for northern Sweden using small-scale data on riparian plant-species numbers from the free-flowing Vindel River, spanning shore sections from 0.5 to $1000 \mathrm{~m}$ long $(n=66$; R. Jansson, unpublished data). Furthermore, we compiled large-scale data from published records of plant species numbers in specific areas (e.g., parishes and provinces) of northern Sweden ( $n=14$; Ericsson 1982, 1984, Mascher 1990, Danielsson 1994). Finally, we counted the total number of plant species occurring in northern Sweden (i.e., the provinces Härjedalen and Hälsingland, and all provinces north of these, covering 239000 $\mathrm{km}^{2}$ ) according to distribution maps in Mossberg et al. (1992). Since a large proportion of the plant species in the boreal zone are found in riparian zones at least occasionally, we did not filter the species lists to exclude some species (Zobel 1997), with the exceptions mentioned below. Since we only wanted to quantify the native species pool from which species colonizing riparian zones in boreal forests are drawn, we excluded species exclusively occurring in marine coastal habitats $(n=37)$. Moreover, we always excluded exotic and nonresidential species, not because they do not contribute to the species pool, but because it is virtually impossible to estimate their true numbers. We also excluded planted and extinct species. Species-area data from Alberta were scarcer. We used the sites sampled along free-flowing rivers in the present study. We also counted the total number of species occurring in Alberta according to Moss (1983). We excluded the grassland-dominated southeastern part of Alberta (i.e., to the south of a line drawn from Mount Rae, near Calgary, and the point where the North Saskatchewan River crosses the province border), thus excluding species occurring exclusively in this part $(n=67)$ for the same reason that we excluded coastal marine species. We wanted to quantify the species pool from which species colonizing riparian zones in boreal forests are drawn. Thus, the area covered by the species pool study in North America was $617000 \mathrm{~km}^{2}$. As for the studies in Sweden, we excluded exotic, nonresidential, planted, and extinct species. For both regional floras, we calculated the number of species belonging to different trait groups. We also counted how many species, genera, and families the regional native species pools had in common. If there were systematic differences between continents in how species are delimited, this would bias intercontinental comparisons. Although species tend to be more narrowly defined in some European countries compared to North America, this is not the tradition of Scandinavian botanists. Moreover, botanists working with boreal floras often have good knowledge about other boreal floras and of distribution patterns of boreal taxa, reducing the risk for systematic differences in species delimitations. In cases where species were shared between the study areas, they were delimited in the same way in most cases.

Response to flow regulation.-We compared the response of local, riparian plant-species numbers (including and excluding exotics) and their cover (herbs + dwarf shrubs and trees + shrubs) to flow regulation between Europe and North America by performing two-way fixed-effects ANOVAs with continent (Europe vs. North America) and the type of water-level regime (free-flowing reaches, storage reservoirs, and reaches downstream of dams) as factors.

We also quantified the degree of convergence or parallel evolution in the number of riparian plant-species (including exotics) by estimating the fraction of variance explained by the type of water level regime (freeflowing reaches, storage reservoirs, and reaches downstream of dams) relative to the total variance. We also estimated the fraction of variance explained by the continental affiliation of a site, exactly following the methodology of Schluter and Ricklefs (1993). Variation among sites in species numbers were partitioned into the following components:

$$
\sigma_{\text {total }}^{2}=\sigma_{\text {habitat }}^{2}+\sigma_{\text {region,main }}^{2}+\sigma_{\text {habitat } \times \text { region }}^{2}+\sigma_{\text {error }}^{2}
$$

where $\sigma_{\text {habitat }}^{2}$ is the portion of total variance attributable to the effects of habitat (type of water level regime), $\sigma_{\text {region,main }}^{2}$ is the main effect of region on riparian species numbers, and $\sigma_{\text {habitat } \times \text { region }}^{2}$ is the interaction between habitat and region. Then we estimated the variance components $(V)$ with the minimum norm quadratic unbiased method. The regional component was calculated as the sum of the main effect of region and the habitat/region interaction, divided by the total variance. To adjust for the fact that both habitat and region were fixed factors but were analyzed as random ones, the components were multiplied with $(x-1) / x$, where $x$ is the number of groups per factor, i.e., $x=3$ for the habitat component and $x=2$ for the regional component (Schluter and Ricklefs 1993). 
FIG. 2. The floristic similarity decreases with the distance between $200 \mathrm{~m}$ long river margin sites. The graph shows the relationship between Simpson's index of similarity (the proportion of the species in the more species-poor sample also present in the other sample) and the distance between sites, for comparisons between free-flowing sites (solid circles) and comparisons between storage reservoirs and freeflowing sites (open circles), all situated in northern Sweden. The regression line is based on comparisons between free-flowing sites only and was used as a null model to evaluate differences in species composition between regulated and free-flowing sites.
- between free-flowing sites

$\circ$ regulated vs. free-flowing sites

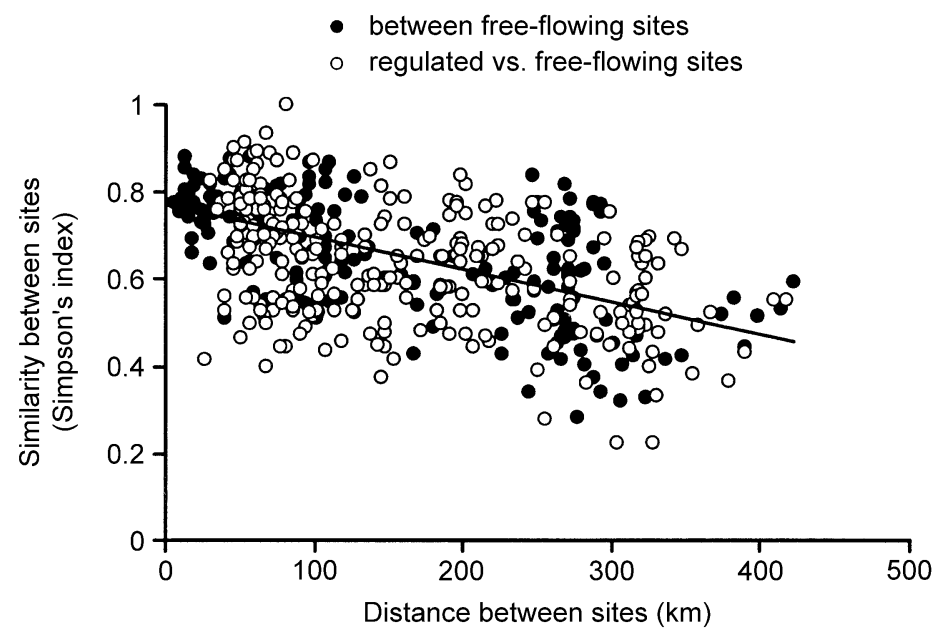

We also asked if there were intercontinental differences in how much the species composition had changed following river regulation. We did this by assessing how much species composition (including exotics) differed between free-flowing and regulated rivers. To estimate the difference in species composition that is unrelated to differences in species richness (which were large for some comparisons), we calculated the floristic similarity among sites using Simpson's index. This index is the proportion of species in the more species-poor sample that also occur in the other sample in the comparison. Thus, it does not incorporate differences due to differences in species richness as most other indices, such as Jaccard's index, do. Because close-lying sites are more similar than distant ones (Nekola and White 1999), we factored out variation in similarity caused by varying distances among sites by the following method. First, we constructed a null model by estimating the relationship between similarity and distance between sites by linear regression, using only data from free-flowing rivers (Fig. 2). Separate null models were constructed for the North American and European data. Second, we calculated the similarity between all regulated and all free-flowing sites. Third, we calculated the difference between these observed similarity values and the similarity values expected from the null model. This resulted in many difference values for each regulated site (12 in Canada, 20 in Sweden). To ensure statistical independence of values, we used the average of these deviation values per regulated site for all statistical tests. We tested whether the mean of these mean deviates differed statistically from zero, which would imply that the regulated sites were more or less different in species composition from the free-flowing sites than expected from the null model, using one-sample $t$ tests (two-tailed probability). Finally, we tested for differences between the continents in how much the regulated river-margins deviated in similarity from free-flowing ones, using two-tailed $t$ tests. For the similarity tests, we used all sites sampled in North America (five storage reservoirs, six reaches downstream of dams, and 12 free-flowing sites), and created a matching European dataset by selecting all storage reservoirs (15 sites) and reaches downstream of dams (seven sites) sampled for a previous study (Jansson et al. 2000), and then selected the closest free-flowing river-margin site in the same data set for each regulated one (20 sites).

We also compared the mean number of native and exotic species per site among river margins in North America, subject to different types of water-level regime (free-flowing reaches, storage reservoirs, and reaches downstream of dams), using one-way ANOVAs. Furthermore, we calculated the correlation between the numbers of exotic and native species per site, using Pearson's product-moment correlation, and the correlation between the number of exotics per site and the environmental variables, using Spearman rank-order correlation.

For all analyses of species richness, we calculated an area-weighted value of species richness to account for differences in sample area due to differences in the widths of river margins. We did this by dividing the number of species for each site by the $\log _{10}$ of area sampled. These area-weighted values are not reported in the results, since they always gave similar results as when using unweighted species counts.

For all the statistical tests we used the computer program SPSS version 9.0 and 10.0 (SPSS 2000). To assess the risk of committing Type II errors, we calculated the powers of the statistical tests, using PASS version 6.0 (NCSS 1997).

\section{RESUlts}

\section{Riparian zones along free-flowing rivers}

The North American study sites were on average wider (leading to larger areas), had higher bank elevation, were more exposed to wave and flow disturbance, and had more fine-grained and heterogeneous 
TABLE 2. Environmental variables compared between river margins along free-flowing rivers in Europe (northern Sweden) and North America (Alberta and British Columbia).

\begin{tabular}{|c|c|c|c|c|c|c|}
\hline \multirow[b]{2}{*}{ Category } & \multicolumn{3}{|c|}{ Europe (122 sites) } & \multicolumn{3}{|c|}{ North America (12 sites) } \\
\hline & Mean & $1 \mathrm{SD}$ & Range & Mean & $1 \mathrm{SD}$ & Range \\
\hline Bank area $\left(\mathrm{m}^{2}\right)$ & 4500 & 5050 & $430-31700$ & 5790 & 6050 & $1160-23400$ \\
\hline Bank height (m) & 2.0 & 0.96 & $0.4-4.9$ & 2.8 & 2.73 & $1.3-9.9$ \\
\hline Exposure & 2.6 & 0.75 & $1-4$ & 3.2 & 1.01 & $2-4$ \\
\hline Substrate fineness & 1.9 & 5.73 & $-10.0-11.7$ & 4.8 & 1.42 & $2.8-6.4$ \\
\hline Substrate heterogeneity & 3.8 & 1.60 & $1-7$ & 5.1 & 1.93 & $2-8$ \\
\hline
\end{tabular}

soils (Table 2). The ranges of values of the variables mostly overlapped between continents, but substrate fineness ranged wider on the European study sites, and the North American site with the highest bank elevation was twice the height of the highest European one (Table 2). According to stepwise multiple regression, the species richness of the free-flowing European sites varied with the environmental variables as described by the following equation:

$$
S=2.4+23.3 \log A-0.11 F^{2}+1.9 H
$$

where $S$ is the number of species, $A$ the sample area, $F^{2}$ the square of substrate fineness, and $H$ is substrate heterogeneity $\left(R_{\mathrm{adj}}^{2}=0.32, P<0.0001\right)$. The mean predicted number of species per site for the free-flowing North American sites using this equation was 93.0 species $(95 \%$ mean predicted confidence interval: 88.0-98.0 species). This exceeds the mean observed for the European sites by 6.5 species, but is less than the minimum detectable difference between the continents (14.4 species) given sample size and variance, according to power analysis. The mean number of species per North American site predicted by the equation differed from the observed mean species richness by only an average of 0.9 species if exotics are included, and by 7.6 species for native species only.

The mean number of species and genera (including exotics) per free-flowing river-margin site did not differ

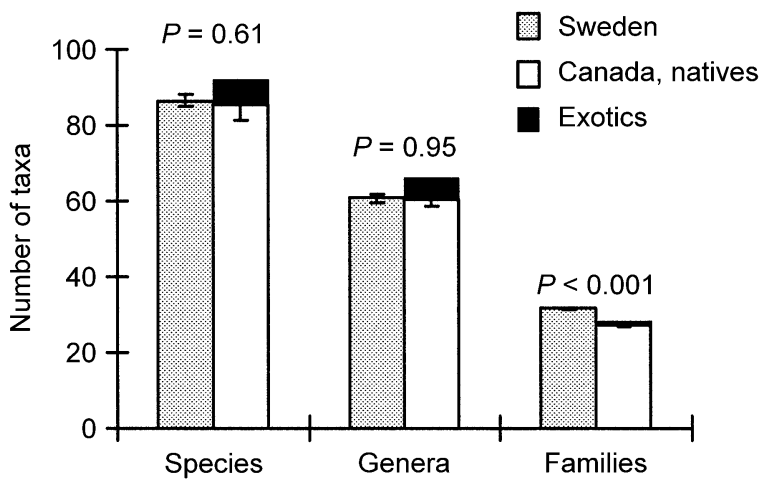

FIG. 3. The mean number of species, genera, and families on $200 \mathrm{~m}$ long sections of river margin along free-flowing rivers compared between Europe (northern Sweden, 122 sites) and North America (Alberta and British Columbia in Canada, 12 sites). $P$ values are from two-tailed $t$ tests of native taxa. Error bars denote \pm 1 SE for mean number of native species. significantly between continents $(P=0.11$, and $P=$ 0.13 , respectively), but the mean number of families was higher in Europe $(P<0.001$, two-tailed $t$ tests; Fig. 3). The mean number of native species and genera per free-flowing river-margin site did not differ significantly between continents $(P=0.61$ and $P=0.95$, two-tailed $t$ tests; Fig. 3). We found no exotic species on the 122 sites along free-flowing rivers in northern Sweden, while there were on average 6.4 (range 0-15) exotics per free-flowing site in North America (Table $3)$. The mean number of woody species per site was higher in North America $(P<0.001)$, but the other groups of species did not differ significantly between continents $(P>0.05$, Bonferroni corrected two-tailed $t$ tests, Table 3 ). When dividing the woody species into tree species (maximum height $>5 \mathrm{~m}$ ) and shrub + dwarf shrub species $(<5 \mathrm{~m})$, the difference between continents remained significant only for shrubs + dwarf shrubs $(P<0.001$, two-tailed $t$ test, Table 3$)$. Neither the percentage cover of trees and shrubs, nor the percentage cover of herbs and dwarf shrubs differed significantly between free-flowing riparian zones on the two continents $(P>0.40$, two-tailed $t$ tests, Table 3$)$.

A large proportion of the species in the native species pools were also found on the studied river-margin sites. On 122 sites along free-flowing rivers in northern Sweden (combined area 54.6 ha), we found $40 \%$ of the species, $49 \%$ of the genera, and $69 \%$ of the families in the native species pool of northern Sweden. Many riparian taxa occurred in both regions. Forty-nine percent of the species, $77 \%$ of the genera, and $95 \%$ of the families that we found on all the free-flowing rivermargin sites in northern Sweden combined, were also found in the native species pool of Alberta. Sixty-two percent of the species, $77 \%$ of the genera, and $94 \%$ of the families found on the free-flowing river-margin sites in North America combined (excluding exotics) were also present in the native species pool of northern Sweden. Note that these proportions are not comparable between continents; the regional native species pool of Alberta contained more species because it was sampled from an area more than twice the size of northern Sweden. The mean Jaccard similarity between freeflowing sites in Europe and North America was $s=$ 0.06 for species, $s=0.22$ for genera, and $s=0.50$ for families. This is to be compared with the mean Jaccard similarities among the European free-flowing sites, 
TABLE 3. To test for differences in the composition of riparian floras, plant cover and the number of species per site in different groups were compared between river margins along free-flowing rivers in Europe (northern Sweden) and North America (Alberta and British Columbia).

\begin{tabular}{|c|c|c|c|c|c|}
\hline \multirow[b]{2}{*}{ Category } & \multicolumn{2}{|c|}{ Mean \pm 1 SE } & \multirow[b]{2}{*}{$P \S$} & \multirow{2}{*}{$\begin{array}{c}\text { Mean } \\
\text { difference } \\
(\% \text { of } \\
\text { European } \\
\text { mean) }\end{array}$} & \multirow{2}{*}{$\begin{array}{c}\text { Minimum } \\
\text { detectable } \\
\text { difference\| ( } \% \\
\text { of European } \\
\text { mean) }\end{array}$} \\
\hline & $\begin{array}{l}\text { Europe } \\
(122 \text { sites })\end{array}$ & $\begin{array}{l}\text { North America } \\
\text { (12 sites) }\end{array}$ & & & \\
\hline \multicolumn{6}{|l|}{ Plant cover $(\%)$} \\
\hline Trees and shrubs $\dagger$ & $39 \pm 4.0$ & $45 \pm 5.4$ & 0.40 & 15 & 49 \\
\hline Herbs and dwarf shrubs $\ddagger$ & $55 \pm 3.0$ & $55 \pm 5.0$ & 0.96 & 0 & 29 \\
\hline \multicolumn{6}{|l|}{ Geographical origin of species } \\
\hline Exotic species & $0.0 \pm 0.00$ & $6.4 \pm 1.54$ & $<\mathbf{0 . 0 0 0 1}$ & $\cdots$ & $\cdots$ \\
\hline Native species & $86.5 \pm 1.52$ & $85.4 \pm 3.95$ & 0.61 & 1 & 14 \\
\hline \multicolumn{6}{|l|}{ Growth form } \\
\hline $\begin{array}{l}\text { Forbs, ferns, club mosses and horsetails } \\
\quad \text { (excluding exotics) }\end{array}$ & $48.2 \pm 1.04$ & $\begin{array}{c}49.8 \pm 2.86 \\
(44.8 \pm 2.16)\end{array}$ & $\begin{array}{l}0.63 \\
0.33\end{array}$ & $\begin{array}{l}3 \\
7\end{array}$ & $\begin{array}{l}18 \\
14\end{array}$ \\
\hline $\begin{array}{l}\text { Graminoids } \\
\quad \text { (excluding exotics) }\end{array}$ & $22.8 \pm 0.52$ & $\begin{array}{c}22.3 \pm 1.84 \\
(20.8 \pm 1.659)\end{array}$ & $\begin{array}{l}0.74 \\
0.25\end{array}$ & $\begin{array}{l}2 \\
9\end{array}$ & $\begin{array}{l}24 \\
21\end{array}$ \\
\hline Woody species & $15.6 \pm 0.32$ & $19.7 \pm 0.91$ & 0.00019 & 26 & 17 \\
\hline Tree species (maximum height $>5 \mathrm{~m}$ ) & $5.8 \pm 0.19$ & $5.3 \pm 0.57$ & 0.45 & 9 & 11 \\
\hline Shrub and dwarf shrub species $(<5 \mathrm{~m})$ & $9.8 \pm 0.29$ & $14.3 \pm 0.64$ & $<\mathbf{0 . 0 0 0 1}$ & 46 & 20 \\
\hline Evergreen species & $9.3 \pm 0.33$ & $6.7 \pm 0.81$ & 0.017 I & 28 & 27 \\
\hline \multicolumn{6}{|l|}{ Life span } \\
\hline Perennial species & $81.7 \pm 1.40$ & $83.5 \pm 4.20$ & 0.70 & 2 & 16 \\
\hline (excluding exotics) & & $(79.3 \pm 3.73)$ & 0.61 & 3 & 14 \\
\hline Annuals and biennial species & $4.5 \pm 0.25$ & $7.8 \pm 1.92$ & 0.11 & 70 & 120 \\
\hline (excluding exotics) & & $(5.9 \pm 1.38)$ & 0.11 & 31 & 80 \\
\hline
\end{tabular}

Notes: For growth form and life span, values excluding exotic species are given, if different. Significant $(P<0.05) P$ values are boldfaced.

$\dagger$ Data from 35 European sites.

$\ddagger$ Data from 80 European sites.

$\S$ Results from $t$ tests, two-tailed probability.

$\|$ The smallest difference in mean values detectable by the test according to power analysis, given the sample size and variance, and assuming normal distribution.

II Not significant at $\alpha=0.05$ when the Type I error rate was adjusted for the number of tests, using sequential Bonferroni tests, i.e., a sequential procedure (Holm 1979) of the Dunn-Šidák method (Sokal and Rohlf 1995).

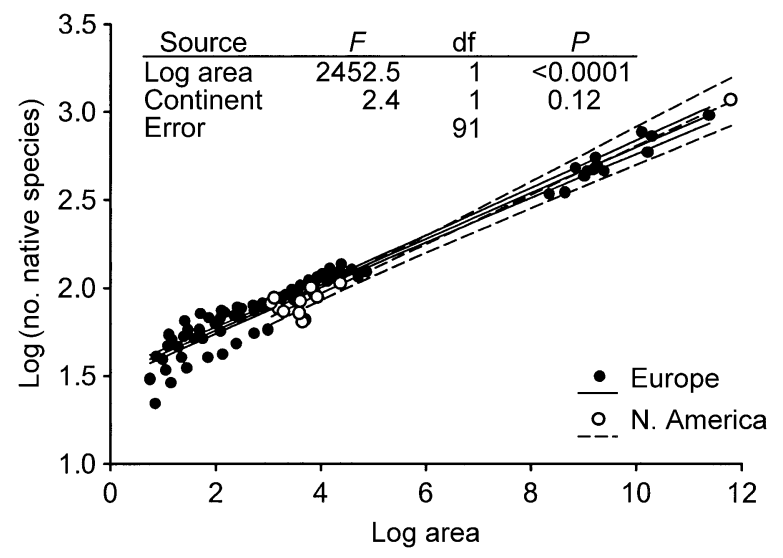

FIG. 4. The relationship between native plant species numbers and area $\left(\log _{10}\right.$ values, based on areas in square meters) for local riparian floras along free-flowing rivers, and for regional floras. Data are from northern Sweden (local data from Vindel River, $n=81$ ) and Alberta and British Columbia $(n=13)$. The lines are linear least-squares regressions with $95 \%$ confidence bands. Inset: the results of a univariate ANCOVA ( $F$ and $P$ values), where the effect of area was significant, but continental affiliation (Europe vs. North America) was not. which were $s=0.37$ for species, $s=0.50$ for genera, and $s=0.64$ for families.

\section{Plant species pools}

The relationships between the number of native plant species and area for Europe vs. North America did not differ significantly from each other according to univariate ANCOVA $(P=0.12$, Fig. 4). We counted 1191 plant species in Alberta (Table 4). The predicted number of species in Alberta from the northern Swedish species-area equation was 1060 species (95\% confidence interval: 751-1495 species). Thus, we cannot refute the null hypothesis that the regional plant species pools did not differ in size between the continents.

The native species pools of Alberta and northern Sweden shared few species but many genera and families. The species pools shared 320 species, 224 genera, and 80 families, which is $27 \%$ of the species, $59 \%$ of the genera, and $83 \%$ of the families in Alberta (Table 4 ). The proportions of species grouped after growth form and life span were similar between the regional floras (Table 4). However, as for the river-margin sites, there were more woody species in Alberta compared to northern Sweden (138 species or $12 \%$ of the flora, 
TABLE 4. Numbers of species, genera, and families, as well as the numbers and proportions of species classified according to growth form and life span, in the native vascular-plant species pools of northern Sweden and Alberta (excluding the southeastern part dominated by prairies). Exotic, nonresidential, planted, and extinct species are excluded.

\begin{tabular}{|c|c|c|c|c|c|c|c|}
\hline \multirow[b]{2}{*}{ Category } & \multicolumn{2}{|c|}{ Northern Sweden } & \multicolumn{2}{|c|}{ Alberta } & \multirow[b]{2}{*}{ Predicted $\ddagger$} & \multirow{2}{*}{$\begin{array}{l}\text { Number of taxa } \\
\text { shared between } \\
\text { floras }\end{array}$} & \multirow{2}{*}{$\begin{array}{c}\text { Proportion } \\
\text { shared taxa } \\
(\% \text { of Alberta) }\end{array}$} \\
\hline & No. & $\begin{array}{c}\text { Proportion } \\
(\%)\end{array}$ & No. & $\begin{array}{c}\text { Proportion } \\
(\%)\end{array}$ & & & \\
\hline \multicolumn{8}{|l|}{ Total number of taxa } \\
\hline Species & 910 & & 1191 & & 1060 & 320 & 27 \\
\hline Genera & 366 & & 380 & & & 224 & 59 \\
\hline Families & 93 & & 96 & & & 80 & 83 \\
\hline \multicolumn{8}{|l|}{ Growth form } \\
\hline $\begin{array}{l}\text { Forb, fern, club moss, } \\
\text { and horsetail species }\end{array}$ & 624 & 68 & 782 & 66 & & 206 & 26 \\
\hline Graminoid species & 208 & 23 & 271 & 23 & & 86 & 32 \\
\hline Woody species & 77 & 9 & 138 & 12 & 94 & 27 & 20 \\
\hline $\begin{array}{l}\text { Tree species } \\
\quad(\text { maximum height } \\
\quad>5 \mathrm{~m})\end{array}$ & 16 & 2 & 28 & 2 & 18 & 1 & 4 \\
\hline $\begin{array}{l}\text { Shrub and dwarf } \\
\text { shrub species } \\
(<5 \mathrm{~m})\end{array}$ & 61 & 7 & 110 & 9 & 58 & 27 & 25 \\
\hline Evergreen species & 52 & 6 & 68 & 6 & & 33 & 49 \\
\hline \multicolumn{8}{|l|}{ Life span } \\
\hline Perennial species & 755 & 83 & $1037 \dagger$ & 88 & & 293 & 32 \\
\hline $\begin{array}{l}\text { Annuals and biennial } \\
\text { species }\end{array}$ & 155 & 17 & $142 \dagger$ & 12 & & 27 & 19 \\
\hline
\end{tabular}

$\dagger$ Of the 1191 species classified.

$\ddagger$ The predicted number of species in Alberta from species-area equation using data derived from Northern Sweden.

compared to 77 species or $8 \%$ in northern Sweden). There were 94 woody species predicted in Alberta from the northern Swedish species-area equation (95\% confidence interval: 43-203 species). The number of shrub + dwarf shrub species (maximum height $<5 \mathrm{~m}$ ) was 110 species or $9 \%$ in Alberta vs. 61 species or $7 \%$ in

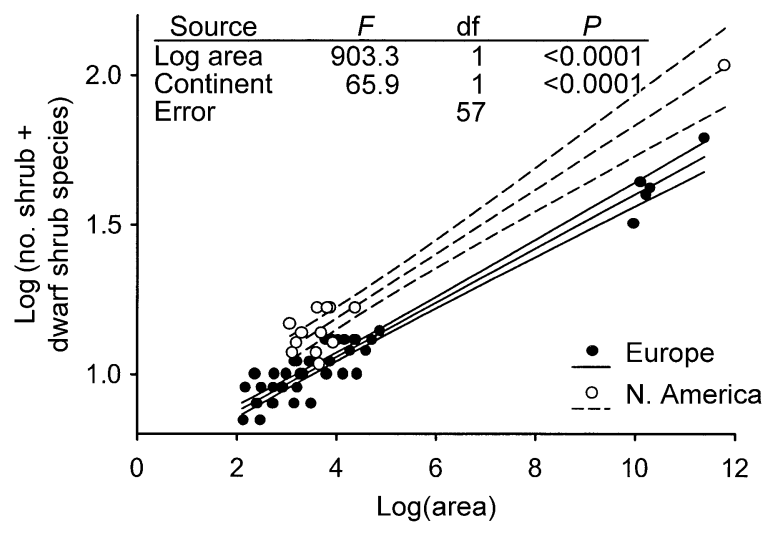

FIG. 5. The relationship between the number of shrub and dwarf shrub species and area ( $\log _{10}$ values, based on areas in square meters) for local riparian floras along free-flowing rivers, and regional floras. Data are from northern Sweden ( $n$ $=47$ ) and Alberta and British Columbia $(n=13)$. The lines are linear least-squares regressions with $95 \%$ confidence bands. Inset: the results of a univariate ANCOVA ( $F$ and $P$ values), where the effects of both area and the continental affiliation (Europe vs. North America) were significant. Only sites $\geq 10 \mathrm{~m}^{2}$ were included, because individual plants are so large that only a few can occur in plots below this size, causing nonlinearity of the curve (Rosenzweig 1995). northern Sweden. This difference was reflected in a difference in the relationship between the number of shrub + dwarf shrub species and area between the continents: The North American regression line had higher elevation $(P<0.0001$, univariate ANCOVA, Fig. 5). There were 58 shrub + dwarf shrub species predicted in Alberta from the northern Swedish species-area equation (95\% confidence interval: 45-76 species). Moreover, there were more tree species (maximum height $>5 \mathrm{~m}$ ) in Alberta compared to northern Sweden: We counted 28 tree species in Alberta, compared to 16 species in northern Sweden. There were 18 tree species predicted in Alberta from the northern Swedish species-area equation (95\% confidence interval: 13-25 species).

\section{Response to flow regulation}

The riparian floras did not differ significantly in their response to flow regulation between the continents. The type of water level regime had a major impact on riparian plant-species richness, but the effect of continent and the interaction between water level regime and continent were not significant, according to two-way fixed-effects ANOVA (Fig. 6A, Table 5). Species richness (including exotics) on margins along storage reservoirs was significantly lower than along free-flowing rivers and reaches downstream of dams $(P<0.0001$ and $P=0.001$, respectively), but the free-flowing rivers and reaches downstream of dams did not differ significantly from each other $(P=0.47)$, according to multiple comparisons (Tukey's tests). The qualitative 

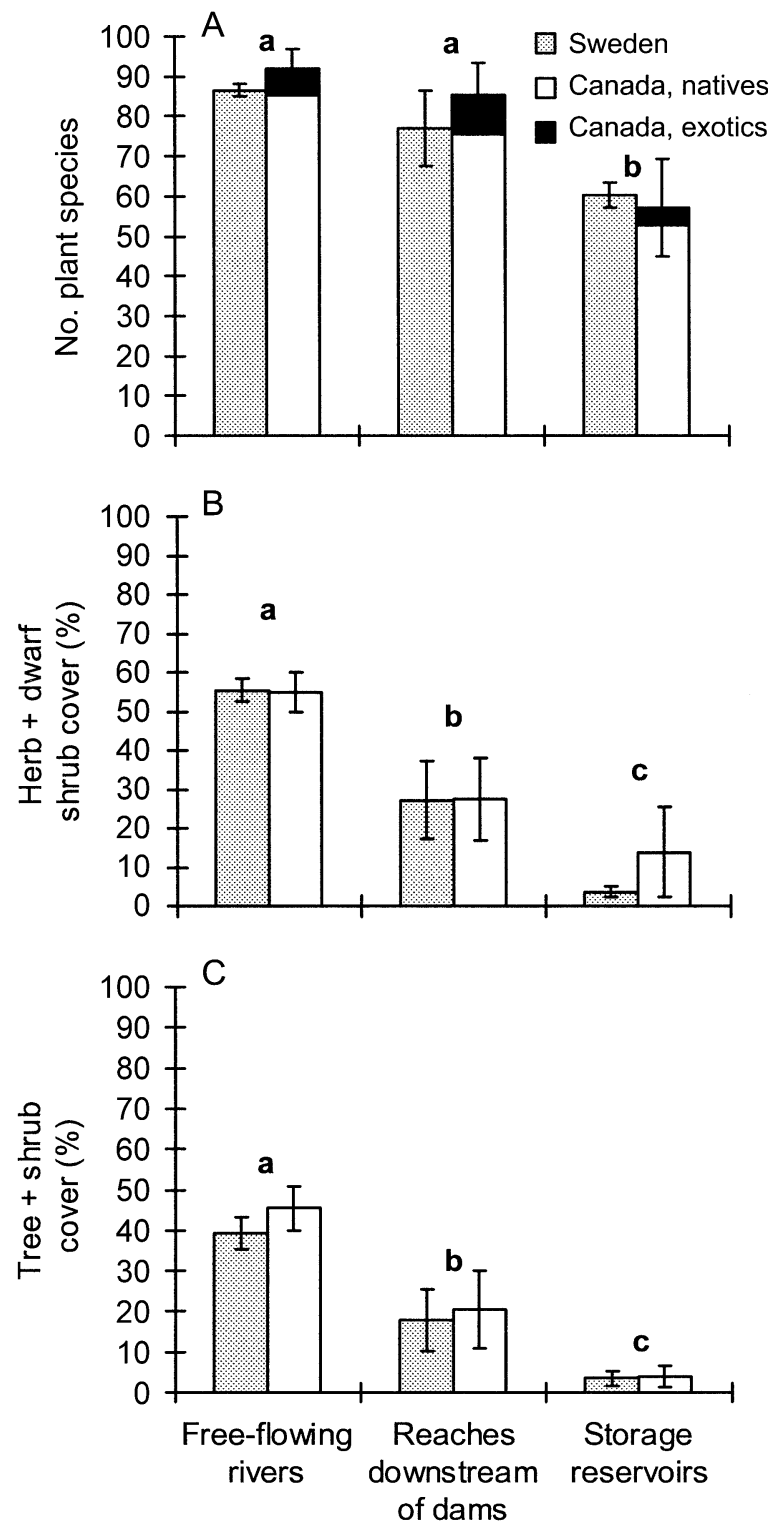

FIG. 6. Comparison of (A) the mean number of plant species, (B) percentage cover of herbs and dwarf shrubs, and (C) percentage cover of trees and shrubs, between $200 \mathrm{~m}$ long river margins subject to different water level regimes in $\mathrm{Eu}-$ rope (northern Sweden) and North America (Alberta and British Columbia). There was no significant effect of region (Europe vs. North America) on any of these three parameters. Error bars denote $\pm 1 \mathrm{SE}$ for mean values (including exotics). Pairs of bars with different superscripts are significantly different between types of water level regime $(P<0.05$, Tukey's tests). There were 122 free-flowing sites, 8 unimpounded reaches downstream of dams, and 53 storage reservoirs from northern Sweden. The corresponding number of sites from Alberta and British Columbia were 12, 6, and 5, respectively.

results remained the same if exotics were excluded. The percentage cover of herbs + dwarf shrubs and trees + shrubs differed between types of water-level regime, but the effect of continent and the interaction between continent and water-level regime were not significant, according to two-way fixed-effects ANOVAs (Fig. 5B, $\mathrm{C}$, Table 5). All three types of water-level regime differed significantly from each other, with the highest percentage cover on margins along free-flowing rivers, lower on margins along reaches downstream of dams, and lowest on margins along storage reservoirs $(P<$ 0.05, Tukey's tests).

The index of convergence in the number of riparian plant-species (including exotics) subject to the three types of water-level regime was $I_{\mathrm{C}}=0.33$, while the index for the importance of regional affiliation was $I_{\mathrm{R}}$ $=0$. Thus, none of the variance in riparian species numbers was statistically explained by the continental affiliation of a riparian site.

Neither the European nor the North American storage reservoirs differed more in riparian plant-species composition (Simpson's index of similarity) from freeflowing sites, compared to what was expected from the null models $(P=0.21$ and $P=0.85$, one-sample $t$ tests, Fig. 7). Neither did the European reaches downstream of dams $(P=0.052)$, but the North American ones were significantly more similar to free-flowing sites than the free-flowing sites were among themselves ( $P=0.010$, one-sample $t$ test, two-tailed probability, Fig. 7). We found no significant difference between the continents in how much the storage reservoirs deviated in species composition from free-flowing sites $(P=$ 0.70 , two-tailed $t$ test, Fig. 7). In contrast, the North American reaches downstream of dams were significantly more similar to the free-flowing sites than the European ones ( $P=0.001$, two-tailed $t$ test, Fig. 7).

When comparing plant-species richness among North American riparian zones subject to different types of water-level regime, storage reservoirs had fewer native species per site compared to free-flowing sites $(P<0.05$, Tukey's test $)$, while sites along free-flowing reaches and reaches downstream of dams did not differ significantly from each other $(P>0.05$, Tukey's test; $F_{2,20}=5.1, P=0.016$, one-way ANOVA). The number of exotic species did not differ significantly between types of water-level regime $\left(F_{2,20}=1.5, P=0.25\right.$, oneway ANOVA). There were $9.7 \pm 2.8$ exotic species per site (mean $\pm 1 \mathrm{SE}$ ) along unimpounded reaches downstream of dams ( $11 \%$ of the total number of species per site), $3.8 \pm 2.2$ species per site along storage reservoirs $(7 \%)$ and $6.4 \pm 1.5$ species per site along free-flowing rivers $(7 \%)$. Of a total of 405 species recorded on 24 North American river-margin sites (12 free-flowing and 12 regulated), 35 species or $9 \%$ were exotics. The exotics were all herbs or graminoids. The number of native and exotic species per site did not covary significantly ( $r=0.17, P=0.42$, Pearson's product-moment correlation). The more coarse-grained and more heterogeneous the substrate composition of riparian soils, the more exotic species there were $(r=$ $-0.53, P=0.0074$, and $r=0.43, P=0.037$, respectively; Spearman rank-order correlation). Substrate fineness and heterogeneity were negatively correlated, 
TABLE 5. Results of two-way fixed-effects ANOVAs on the total number of plant species (including exotics), herb + dwarf shrub cover, and tree + shrub cover, for river-margin sites subject to different types of water-level regime and situated on different continents (Europe and North America).

\begin{tabular}{|c|c|c|c|c|c|}
\hline Source of variation & $\begin{array}{l}\text { Sums of } \\
\text { squares }\end{array}$ & df & $\begin{array}{l}\text { Mean } \\
\text { squares }\end{array}$ & $F$ & $P \dagger$ \\
\hline \multicolumn{6}{|l|}{ Number of species } \\
\hline Water-level regime & 11990.8 & 2 & 5995.4 & 16.18 & $<\mathbf{0 . 0 0 0 1}$ \\
\hline Continent (Europe or North America) & 188.6 & 1 & 188.6 & 0.51 & 0.48 \\
\hline Interaction & 331.6 & 2 & 165.8 & 0.45 & 0.64 \\
\hline Error & 74123.4 & 200 & 370.6 & & \\
\hline \multicolumn{6}{|l|}{ Herb and dwarf shrub cover } \\
\hline Water-level regime & 29503.0 & 2 & 14751.5 & 29.87 & $<\mathbf{0 . 0 0 0 1}$ \\
\hline Continent (Europe or North America) & 166.8 & 1 & 166.8 & 0.34 & 0.56 \\
\hline Interaction & 364.8 & 2 & 182.4 & 0.37 & 0.69 \\
\hline Error & 78037.7 & 158 & 493.9 & & \\
\hline \multicolumn{6}{|l|}{ Tree and shrub cover§ } \\
\hline Water-level regime & 19063.9 & 2 & 9532.0 & 29.22 & $<\mathbf{0 . 0 0 0 1}$ \\
\hline Continent (Europe or North America) & 147.1 & 1 & 147.1 & 0.45 & 0.50 \\
\hline Interaction & 108.2 & 2 & 108.2 & 0.17 & 0.85 \\
\hline Error & 36858.9 & 113 & 370.6 & & \\
\hline
\end{tabular}

$\dagger$ Values where $P<0.05$ are boldfaced.

\$ Data from 35 European sites.

$\S$ Data from 80 European sites.

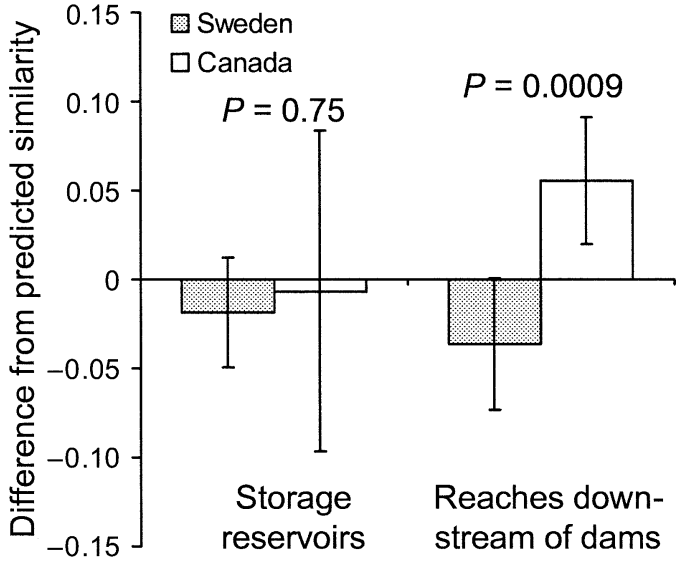

FIG. 7. Mean difference between the actual similarity (Simpson's index) in species composition between regulated and free-flowing sites and the expected similarity based on the distance between sites (Fig. 2). Ninety-five percent confidence limits of one-sample $t$ tests of whether bars deviate from zero are inset on the bars as vertical lines. The storage reservoirs sampled in North America and Europe, as well as the reaches downstream of dams in Europe, did not differ significantly more in species composition from free-flowing river-margins than the free-flowing sites did among themselves (one-sample $t$ tests, two-tailed probability). In contrast, reaches downstream of dams in North America were more similar to free-flowing ones than expected from the similarity-distance null model (Fig. 2). The European reaches downstream of dams deviated significantly more from predicted similarity values compared to the North American ones $(P=$ 0.0009 ), but there was no significant difference between Europe and North America for the storage reservoirs $(P=0.75$, two-tailed $t$ tests). Bars are mean differences between observed and expected pairwise similarities among 15 storage reservoirs and seven reaches downstream of dams from Sweden, and five storage reservoirs and six reaches downstream of dams from Canada. the coarser grained soils being more heterogeneous $(r$ $=-0.73, P<0.0001$, Spearman rank-order correlation).

\section{DISCUSSION}

\section{Intercontinental comparisons of responses to flow regulation}

The similarity in the response to hydroelectric development suggests that the riparian plant communities on the two continents differed little in their sensitivity to flow regulation. The reason for this similarity is probably that the riparian floras of the two regions are composed of species with similar traits, which made them respond to river regulation in a similar way. The index of convergence in the number of riparian species subject to the three types of water level regime was $I_{\mathrm{C}}$ $=0.33$, which is close to the average of values (mean $I_{\mathrm{C}}=0.34$, range $0.11-0.78, n=12$ ) for comparisons between local sites in different habitat types (Schluter and Ricklefs 1993). In contrast, the mean of the indices of the importance for regional affiliation in the studies reviewed by Schluter and Ricklefs (1993) was $I_{\mathrm{R}}=$ 0.36 (range $0-0.83, n=12$ ), which is to be compared to $I_{\mathrm{R}}=0$ in our study.

Were the study sites on the two continents comparable? The average difference between the North American species richness predicted from the European environmental factor regression and the observed European species richness was only 6.5 species (less than the minimum detectable difference given sample size and variance). This suggests that there were no large biases in riparian environments that could cause large differences in species richness between the two continents. The fact that the predicted species richness per 
North American site was on average only 0.9 species away from the observed number of species, suggests that the boreal riparian species respond to variation in the environmental variables in the equation in the same way on both continents. However, the species richness/ environment equation left a lot of variance in European species richness unexplained $\left(R_{\text {adj }}^{2}=0.32\right)$.

The contrasts between types of water level regime were similar between continents (Fig. 6, Table 5), and are identical to the findings from a comparison of eight rivers in northern Sweden; riparian plant-species numbers were impoverished along storage reservoirs, while reaches downstream of dams did not differ significantly in richness from free-flowing rivers (Jansson et al. 2000). Margins along storage reservoirs are stressful habitats for plants (Jansson et al. 2000). Water levels are often raised at dam closure, and new shorelines are formed in previous uplands (Nilsson et al. 1997). The new margins have unstable and easily eroded soils, and most plant species that will grow there must recolonize after the onset of regulation. In addition, the artificial water level regime exerts stress and disturbance on riparian plants. In the studied storage reservoirs, water levels are low early in the growing season and then continually raised, flooding the entire riparian zone for the rest of the season, a situation to which there is no natural analog in the boreal zone. Consequently, there are no species specifically adapted to this, and the vegetation is mostly constrained to a narrow belt close to the high-water level. Exceptions are scattered individuals of rapidly reproducing annual species that develop early in the season before the reservoir is filled (Nilsson and Keddy 1988), and a few stress-tolerating perennial species, such as Ranunculus reptans, primarily growing where fine-grained soils remain.

Margins along reaches downstream of dams have diversities comparable to those of free-flowing river reaches (Fig. 6), even though water level variation may be large and frequent. This is probably because water level fluctuations may have a largely natural seasonal rhythm, although often highly variable in the short term, and because the riparian zones generally remain within their preregulation limits. The latter is important, given the erosion proneness and impoverished flora of new river margins during the first decades following dam closure (Jansson et al. 2000). The fact that riparian-plant species richness along reaches downstream of dams differed little from free-flowing ones suggest that species richness is not the most sensitive indicator of effects of flow regulation. However, in previous studies (e.g., Nilsson et al. 1991, Jansson et al. 2000) we have documented large differences in species richness among types of water-level regime, and the aim of this study was to test whether those results were valid when comparisons were extended to another biogeographic region. Although not documented in this study, changes in riparian vegetation along unimpounded reaches downstream of dams may still be large, including major geomorphic adjustments followed by successional replacements of plant communities (Ligon et al. 1995, Friedman et al. 1998, Johnson 1998), changes in riparian water tables (Patten 1998), changes in the extent of the riparian zone (Gill 1973), and invasion of exotic species (de Waal et al. 1994, Taylor et al. 1999).

The regulated sites were equally or more similar in species composition to free-flowing sites, compared to what was expected based on the distance between them (Fig. 7). This suggests that the regulated sites were composed of more or less the same species as nearby free-flowing rivers on both continents, although sites along storage reservoirs were more species poor. This also suggests that there was no substantial turnover in species composition following regulation, although turnover in infrequent species would not be detected by our method of comparing similarities. However, a regulated and a parallel free-flowing river in northern Sweden contained similar sets of riparian plant species, although most species had fewer occurrences in the regulated one (Nilsson et al. 1991). Apparently, few species have been able to take advantage of the altered environmental conditions and invade following regulation. The riparian flora is already a filtered subset of the species pool. To survive on regulated river-margins, plants must tolerate recurrent flooding and draining, making it likely that they were already present in some riparian zones before onset of regulation.

The reason why sites along reaches downstream of dams in North America were more similar in species composition to the free-flowing sites than predicted from the null model (Fig. 7) might be that rare, infrequent species were preferentially lost following regulation at the spatial scale studied (although the mean species richness was not significantly lower). If so, the reaches downstream of dams would primarily be composed of species that are present on most free-flowing and regulated sites, producing high similarity indices in comparisons between sites. However, limitations in the sample size do not allow us to test this hypothesis. The intercept for the relationship between floristic similarity and distance between sites in Fig. 2 is at an index of 0.77 . This value matches the similarity between adjacent plots well, which is lower than 1.0 (R. Jansson, unpublished data), due to spatial heterogeneity in species composition and many infrequent species.

The fact that different river systems are developed for hydroelectric purposes by different methods may lead to different regional effects on the riparian flora. Few high-capacity dams interrupted by long, unimpounded reaches, as in western Canada, result in rivers in which high proportions of the riparian zones retain relatively rich riparian floras. Situations with many dams, forming chains of consecutive impoundments, as in northern Sweden, result in high proportions of the river's riparian zones having an impoverished riparian flora. 


\section{Intercontinental comparisons of local riparian-plant and regional diversity}

We found examples of both convergence and divergence in local community composition between the continents, but the most striking result was the high degree of parallelism. Parallelism refers to situations where the composition of both local communities and regional species pools are similar between continents. Numbers of species and genera as well as the trait group composition of species were similar between the continents at both local riparian and regional scales (Tables 2, 3, and Fig. 3). Moreover, the species-area relationship for native species was similar between the continents (Fig. 4). Westoby (1993) considered cases of similar-sized regional species pools to be mere chance events. However, similar-sized species pools would be expected if the organisms have a relatively recent, common origin and if the subsequent processes governing speciation, immigration, and extinction of taxa have been similar between the regions. Both factors are likely to be of importance for the similarity between the two boreal floras. Most genera and families were shared between northern Sweden and Alberta (Table 4), illustrating their common Tertiary origin. Many of these taxa have distributions spanning most of the boreal forest zone (Hultén 1950). Moreover, the boreal biome is continuous except for the Bering Strait, which has been bridged during long periods of lower sea levels, and which has had boreal climate since the Miocene (Keast 1990). Despite this, the regional native species pools had only $27 \%$ of the species of Alberta in common, showing that the floras have had separate recent histories. However, both regions have had similar lateTertiary and Quaternary histories of climatic change, with recurrent changes between glacial and interglacial conditions (Huntley and Webb 1988, Porter 1989). These climatic changes forced large changes in species' geographic distributions, and may have had similar selective and rate-controlling effects on speciation, immigration, and extinction on both continents (Dynesius and Jansson 2000).

One result suggests that local, riparian communities have converged in relation to the regional, native species pools. We found no significant difference in riparian tree-species richness per free-flowing site between the continents (Table 3), although there were more tree species in Alberta than in northern Sweden (Table 4). In contrast, species richness of all woody species (including shrubs and dwarf shrubs) was higher in North America on both river-margins and in the native regional species pool (Tables 2 and 3). Previous studies have reported fewer temperate tree species in Europe compared to North America (Huntley 1993, Latham and Ricklefs $1993 a, b$ ). The difference in the number of tree species between the native species pools indicates that boreal tree species in Europe may also have gone extinct during the Quaternary, as has been documented for temperate tree species (Watts 1988, Bennett 1997). The extinctions of temperate tree species from Europe were probably due to strong reductions in the area of forests (Huntley 1993), as well as displacement and complete loss of some habitats during glacial times, rather than east-west spanning mountain ranges blocking north-south dispersal.

We found evidence that family richness per freeflowing riparian site had diverged between the continents. The number of families was similar between the regional native species pools (93 in northern Sweden and 96 in Alberta), while there were on average 3.9 more families per riparian site in Europe. This difference is difficult to explain, given the similarity in species and generic richness (Fig. 3), and was not due to differences in the taxonomy, because we used the same taxonomy for families in both regions (Krok and Almquist 1994). Instead, the difference in family richness was caused by a few families being much more frequent on the European study sites than the North American ones. There were seven families in Europe occurring on $>60 \%$ of the sites, but on less than $25 \%$ of the North American sites. There were only two such families in North America ( $>60 \%$ of American sites; $<25 \%$ of European ones). Geraniaceae, Empetraceae, and Valerianaceae each contained a single species that was present on more than two-thirds of the European sites, whereas these families were not found on the river-margins in North America.

Which and how many species coexist locally are determined by local, ecological processes and/or regional, evolutionary ones (Terborgh and Faaborg 1980, Cornell 1985, Schluter and Ricklefs 1993, Lawton 1999, Srivastava 1999). It has been argued that if local diversity converges among regions, despite large differences in the sizes of the available species pools, this is evidence that some contemporary, ecological process limits local diversity. In contrast, local species richness may vary in proportion to regional species richness, with no saturation of local communities (Ricklefs 1987, Cornell and Lawton 1992, Zobel 1997). If so, local species richness is limited by the rate new species originate or immigrate to the region, balanced against the rate at which species are lost. Given that local, riparian as well as regional richness was similar between the regions in the present study, could we still find clues to the relative importance of local ecological processes and regional evolutionary processes in determining local, riparian species richness? Competition is the process that has most frequently been hypothesized to limit local species richness (Huston 1999), but many species may coexist without interacting on the $200 \mathrm{~m}$ long strips of river margin studied, by occurring in different subhabitats. Moreover, the river margins are subject to recurrent flood disturbances, setting back the abundance of competitively superior species, allowing competitively inferior species to survive. These factors 
make it unlikely that riparian plant communities at the spatial scale used by us are saturated.

The similarities in the riparian species richness are best explained by similarities in the regional native species pools, caused by relatively recent, common origins and parallel evolution. Local species richness was similar between continents because the species pools in the two regions responded similarly to similar environments. This means that they share distributions of species traits, such as habitat specificity, which are ultimately determined by evolutionary processes working on time-scales that are orders of magnitude longer than the boreal riparian habitat has existed in its current position. The floras have similar trait distributions because they share a common Tertiary origin and because the regions have had largely similar late-Tertiary and Quaternary histories. There are few, if any, vascular plant species occurring exclusively on boreal riverbanks. The boreal riparian species have not spent their recent evolutionary history (the last millions of years) in situ, but in many different biotic and abiotic settings due to the large recurrent climate changes over geological time (Porter 1989, Webb and Bartlein 1992, Bennett 1997). They have only recently $\left(<10^{4}\right.$ years $)$ been recruited to the current, boreal riverbanks.

\section{Magnitude of differences between continents}

Is it fair to conclude that riparian plant diversity patterns and sensitivity to river regulation were similar between the continents? The ability to statistically detect differences between the continents depends on the sample size, the variance as well as the magnitude of the difference. Given that the true mean values are unlikely to be exactly similar, it is necessary to consider what magnitude of difference in mean values could be considered "biologically meaningful." For counts of species numbers in $200 \mathrm{~m}$ long sections of riverbank, differences in mean values between continents of $\sim 10 \%$ or less must be considered small, given the variation within regions. For example, the species richness per European free-flowing site ranged between 34 and 131, with $50 \%$ of the observations between 77 and 98 species. The minimum detectable difference according to power analysis ranged between $11 \%$ and $27 \%$ of the European mean values, except for annual + biennial species richness (120\% including and $80 \%$ excluding exotics; Table 3), raising the possibility that we failed to detect some "biologically meaningful" differences in species richness between continents due to small sample size. However, in the comparisons of species richness of free-flowing sites between continents, where we failed to reject the null hypothesis of no difference, the difference in mean values was $<10 \%$, except for evergreen species $(26 \%)$ and annual + biennial species $(70 \%$ including and $31 \%$ excluding exotics; Table 3). The differences in mean species richness of the regulated sites between the continents were equally small. The mean species richness of the North
American sites along unimpounded reaches downstream of dams differed from the European ones by $11 \%$ including exotics, and by $2 \%$ excluding them. The corresponding values for storage reservoirs were $5 \%$ including, and $12 \%$ excluding exotics.

Given that we estimated plant cover values on 200 $\mathrm{m}$ long riverbank sections by eye, differences in mean values as small as $10 \%$ should not be interpreted biologically. Half of the free-flowing European sites had covers of herbs + dwarf shrubs between $30 \%$ and $77 \%$. The ratio of mean covers of trees + shrubs per freeflowing North American and European site was 1.15 ( $45 \%$ vs. $39 \%$ cover), and the mean covers of herbs + dwarf shrubs were the same between the continents (55\%, Table 3). The differences in plant cover of the regulated sites were equally small between the continents, with ratios of mean cover between continents ranging between 1.01 and 1.13 , except for herbs + dwarf shrubs along storage reservoirs (2.7 times more cover on the North American sites). However, this difference corresponds to a difference of only 10 percentage units in actual cover of herbs + dwarf shrubs (4\% cover of the European, and 14\% cover of the North American sites).

To conclude, in cases where we failed to reject the null hypothesis of no difference between continents, the magnitude of difference in mean value was generally small ( $\sim 10 \%$ or less), and thus biologically unimportant. However, we may have committed Type II errors for evergreens and annuals + biennials along free-flowing rivers, and thus missed relevant differences between the continents.

\section{Exotic species}

The most conspicuous difference between the regions was the absence of species introduced from other continents in the riparian zones of northern Sweden. Exotic species are not completely absent from riparian zones in northern Sweden, but our failure to record a single one on 183 sites (each $200 \mathrm{~m}$ long) is evidence for their rarity. However, subsequent to our fieldwork, one exotic legume species from North America, Thermopsis montana, has established in one of the investigated sites in the Vindel River (M. Dynesius, R. Jansson, M. E. Johansson, and C. Nilsson, personal observations). All the 35 exotic species found by us on river margins in North America are also found in $\mathrm{Eu}-$ rope. All except three species also occur on riverbanks and other disturbed sites in northern Sweden. Some of them are native in northern Sweden, while others probably were introduced by humans long ago from other parts of Europe. These species were also likely to be introduced, deliberately or not, to North America by European immigrants, bringing their agricultural system and garden plants to the new continent. Moreover, Eurasia has a much longer history of coevolution between humans and plants than North America, which could result in more potential invaders to habitats dom- 
inated by humans in North America from Europe than vice versa. Thus, the difference in the number of exotic species reflects the number of species invading the region, and/or a difference in the number of propagules of exotics arriving at each site (or "propagule pressure"; Lonsdale 1999), rather than a difference in invasibility between the regions. Historical differences may also explain why there were more annual and biennial species in the native species pool of northern Sweden than in Alberta (155\% or $17 \%$ vs. $142 \%$ or $12 \%$, Table 4). Many of the annual and biennial species in northern Sweden are found in farmlands or other human-disturbed sites. Many of the species associated with such habitats in Alberta are recently arrived exotics, and were consequently excluded from the count of the native species pool.

Riparian zones generally contain more exotic species than other natural or seminatural vegetation types (Crawley 1987, DeFerrari and Naiman 1994, Kotanen et al. 1998, Stohlgren et al. 1998). The proportion of riparian exotics encountered in North America for all 24 sites combined was $9 \%$, which is on the low side compared to those generally found in the combined flora of other temperate river systems (24-30\%), where proportions of exotics per site can approach 60\% (DeFerrari and Naiman 1994, Planty-Tabacchi et al. 1996). The fact that the number of exotic species per site increased, the more coarse-grained the riparian soil, is consistent with the findings of DeFerrari and Naiman (1994) in the Pacific Northwest of North America. The reason is probably that coarse-grained soils are indicative of areas that are more disturbed by wave and flow action, opening sites for colonization and allowing competitively inferior species to survive. In contrast, Friedman et al. (1996) found that in a semiarid stream, exotics dominated on fine-textured, moist and human-disturbed sediments, whereas native plants dominated on coarse-grained, xeric sediments deposited by a large flood.

\section{Conclusions and Future Perspectives}

The two boreal riparian floras were similar in their sensitivity to hydroelectric exploitation. At the present we do not know under what conditions such similarities are expected. Different evolutionary histories mostly result in different diversity patterns, but also in different characteristics of species, affecting their ability to withstand different human activities (Dynesius and Jansson 2000). Therefore, we hypothesize that responses to human perturbations are more likely to differ between regions when natural diversity patterns differ as well. Comparisons between biogeographic regions of the ecological effects of a similar human disturbance should play a more prominent role in conservation biology, because they allow distinguishing peculiarities of a region from general patterns.

The interest in river rehabilitation is growing due to the need to accommodate increasing demands for man- aging rivers for multiple uses (Boon 1998, Postel et al. 1998, Wissmar and Beschta 1998, Harris 1999). The status of riparian zones is of central importance in efforts to restore river ecosystems, given that they are ecotones between terrestrial and aquatic habitats that control many aspects of riverine ecosystems (Naiman and Décamps 1997, Naiman et al. 2000, Nilsson and Svedmark 2002). The high similarity in riparian plantspecies numbers and in the effects of flow regulation between the continents suggests that it is possible to develop general guidelines for rehabilitation of riparian zones, at least within the boreal forest zone (Naiman et al. 2000). The most important key actions for restoring a specific function or property should be reintroducing aspects of natural flow regimes, minimizing barrier effects of dams, allowing rivers to migrate laterally, reconnecting riparian zones that have been separated from the water-filled channel, and controlling exotic species (Stanford et al. 1996, Poff et al. 1997, Richter et al. 1997, Wissmar and Beschta 1998). For boreal riparian vegetation, some kind of flood mimicking spring floods, followed by sufficiently long periods of low flows, is crucial (Nilsson and Keddy 1988, Hill et al. 1998, Johansson and Nilsson 2002).

Even if the proximate, ecological causes of the assembly of local plant communities (e.g., competition, disturbance, and herbivory) were completely understood, that understanding would be only partial unless we understood how the region where the local communities are set has become occupied with an assemblage of species with specific traits. For example, the present poverty of tree species in Europe compared to North America and Eastern Asia (Latham and Ricklefs $1993 a, b)$ can only be understood in the light of the history of Quaternary extinctions in Europe (Latham and Ricklefs 1993a). Thus, to fully comprehend patterns in species diversity and species vulnerability to human activities, biodiversity researchers must focus on the processes shaping species pools, i.e., speciation, extinction and migration of taxa. Ecologists studying contemporary communities should pay more attention to the progress made in palaeoecology, palaeontology, and systematics (Bennett 1997), because as in many fields, the past holds the key to the present.

\section{ACKNOWLEDGMENTS}

We thank K. Hylander, D. M. Merritt, R. J. Naiman, R. E. Ricklefs, and two anonymous reviewers who greatly improved the manuscript with their comments. We thank all the botanists who helped in identifying specimens collected on Canadian river-margins: G. W. Argus (Salix), J. F. Bain (Senecio), H. E. Ballard (Viola), M. E. Barkworth (Poaceae), T. C. Brayshaw (trees, shrubs, Ranunculaceae), J. M. CanneHilliker (Scrophulariaceae), E. Haber (Pyrola), N. A. Harriman (Juncaceae), B. E. Jonsell (Rorippa), M. Lavin (Astragalus, Oxytropis), G. B. Straley (various), J. C. Semple (Aster, Solidago, Euthamia, Erigeron, Artemisia), S. Snogerup (Juncus, Brassica), and P. Uotila (Chenopodiaceae). E. Carlborg assisted with plant trait group classification. The work was supported by a grant from the Swedish Natural 
Science Research Council (to C. Nilsson). Roland Jansson and M. Dynesius contributed equally to this work.

\section{Literature Cited}

Anonymous. 1979. Streamflow records of Sweden. Liberfōrlag, Stockholm, Sweden.

Anonymous. 1987. Historical streamflow summary, Alberta, to 1986. Water Survey of Canada, Ottawa, Canada.

Anonymous. 1989. Historical streamflow summary, British Columbia, to 1988. Water Survey of Canada, Ottawa, Canada.

Anonymous. 1995. Vattenföring i Sverige. Part 2. Vattendrag till Bottenhavet. Swedish Meteorological and Hydrological Institute, Norrköping, Sweden.

Balmford, A. 1996. Extinction filters and current resilience: the significance of past selection pressures for conservation biology. Trends in Ecology and Evolution 11:193-196.

Bennett, K. D. 1997. Evolution and ecology. The pace of life. Cambridge University Press, Cambridge, UK.

Boon, P. J. 1998. River restoration in five dimensions. Aquatic Conservation: Marine and Freshwater Ecosystems 8: 257-264.

Brown, J. H., and M. V. Lomolino. 1998. Biogeography. Second edition. Sinauer Associates, Sunderland, Massachusetts, USA.

Cody, M. L., and H. A. Mooney. 1978. Convergence versus nonconvergence in mediterranean-climate ecosystems. Annual Review of Ecology and Systematics 9:265-321.

Cornell, H. V. 1985. Local and regional richness of cynipine gall wasps on California (USA) oaks. Ecology 66:12471260 .

Cornell, H. V., and J. H. Lawton. 1992. Species interactions, local and regional processes, and limits to the richness of ecological communities - a theoretical perspective. Journal of Animal Ecology 61:1-12.

Cowling, R. M., P. W. Rundel, P. G. Desmet, and K. J. Esler. 1998. Extraordinary high regional-scale plant diversity in southern African arid lands: subcontinental and global comparisons. Diversity and Distribution 4:27-36.

Crawley, M. J. 1987. What makes a community invasible? Pages 429-454 in A. J. Gray, M. J. Crawley, and P. J. Edwards, editors. Colonization, succession, and stability. Blackwell, Oxford, UK.

Danielsen, F. 1997. Stable environments and fragile communities: does history determine the resilience of avian rain-forest communities to habitat degradation? Biodiversity and Conservation 6:423-433.

Danielsson, B. 1994. Härjedalens kärlväxtflora. SBT-förlaget, Lund, Sweden.

Décamps, H., and E. Tabacchi. 1994. Species richness along river margins. Pages 1-20 in P. S. Giller, A. G. Hildrew, and D. G. Raffaelli, editors. Aquatic ecology. Scale, pattern and process. Blackwell, Oxford, UK.

DeFerrari, C. M., and R. J. Naiman. 1994. A multiscale assessment of the occurrence of exotic plants on the Olympic Peninsula, Washington. Journal of Vegetation Science 5: 247-258.

de Waal, L. C., L. E. Child, P. M. Wade, and J. H. Brock. 1994. Ecology and management of invasive riverside plants. John Wiley and Sons, Chichester, UK.

Dynesius, M., and R. Jansson. 2000. Evolutionary consequences of changes in species' geographical distributions driven by Milankovitch climate oscillations. Proceedings of the National Academy of Sciences, (USA) 97:91159120 .

Dynesius, M., and C. Nilsson. 1994. Fragmentation and flow regulation of river systems in the northern third of the world. Science 266:753-762.

Ericsson, S. 1982. Umeåtraktens kärlväxter. Natur i Norr 1: $2-63$.
Ericsson, S. 1984. Åsele lappmarks kärlväxter. Natur i Norr 3:82-170.

Eriksson, O. 1993. The species-pool hypothesis and plant community diversity. Oikos 68:371-374.

Fox, J. W., J. MacGrady-Steed, and O. L. Petchey. 2000. Testing for local species saturation with nonindependent regional species pools. Ecology Letters 3:198-206.

Friedman, J. M., W. R. Osterkamp, and W. L. Lewis. 1996. Channel narrowing and vegetation development following a Great Plains flood. Ecology 77:2167-2181.

Friedman, J. M., W. R. Osterkamp, M. L. Scott, and G. T. Auble. 1998. Downstream effects of dams on channel geometry and bottomland vegetation: regional patterns in the Great Plains. Wetlands 18:619-633.

Gill, D. 1973. Modification of northern alluvial habitats by river development. Canadian Geographer 17:138-153.

Hare, F. K., and M. K. Thomas. 1974. Climate Canada. Wiley, Toronto, Canada.

Harris, R. R. 1999. Defining reference conditions for restoration of riparian plant communities: examples from California, USA. Environmental Management 24:55-63.

Hill, N. M., and P. A. Keddy. 1992. Prediction of rarities from habitat variables-coastal-plain plants on Nova Scotian lakeshores. Ecology 73:1852-1859.

Hill, N. M., P. A. Keddy, and I. C. Wisheu. 1998. A hydrological model for predicting the effects of dams on the shoreline vegetation of lakes and reservoirs. Environmental Management 5:723-736.

Hjelmqvist, S. 1953. The bedrock of Sweden excluding the Caledonian mountain range. Maps 7 and 8 in M. Lundqvist, editor. National atlas of Sweden. Generalstabens Litografiska Anstalts Förlag, Stockholm, Sweden.

Holm, S. 1979. A simple sequentially rejective multiple test procedure. Scandinavian Journal of Statistics 6:65-70.

Hultén, E. 1950. Atlas över växternas utbredning i Norden. Fanerogamer och ormbunksväxter. Generalstabens Litografiska Anstalts Förlag, Stockholm, Sweden.

Huntley, B. 1993. Species-richness in north-temperate zone forests. Journal of Biogeography 20:163-180.

Huntley, B., and T. Webb III, editors. 1988. Vegetation history. Kluwer Academic, Dordrecht, The Netherlands.

Huston, M. A. 1999. Local processes and regional patterns: appropriate scales for understanding variation in the diversity of plants and animals. Oikos 86:393-401.

Jansson, R., C. Nilsson, M. Dynesius, and E. Andersson. 2000. Effects of river regulation on riparian vegetation: a comparison of eight boreal rivers. Ecological Applications 10:203-224.

Johansson, M.E., and C. Nilsson. 2002. Responses of riparian plants to water-level variation in free-flowing and regulated boreal rivers: an experimental study. Journal of Applied Ecology 39:971-986.

Johnson, W. C. 1998. Adjustment of riparian vegetation to river regulation in the Great Plains, USA. Wetlands 18: 608-618.

Keast, A. 1990. Distribution and origin of forest birds. Pages 45-59 in A. Keast, editor. Biogeography and ecology of forest bird communities. SPB Academic, The Hague, The Netherlands.

Kotanen, P. M., J. Bergelson, and D. L. Hazlett. 1998. Habitats of native and exotic plants in Colorado shortgrass steppe: a comparative approach. Canadian Journal of Botany 76:664-672.

Krok, T. O. B. N., and S. Almquist. 1994. Svensk flora. Fanerogamer och ormbunksväxter. Twenty-seventh edition. Liber Utbildning, Stockholm, Sweden.

Kulling, O. 1953. The bedrock of Sweden excluding the Caledonian mountain range. Maps 7 and 8 in M. Lundqvist, editor. National atlas of Sweden. Generalstabens Litografiska Anstalts Förlag, Stockholm, Sweden. 
Latham, R. E., and R. E. Ricklefs. 1993a. Continental comparison of temperate-zone tree species diversity. Pages 294-314 in R. E. Ricklefs and D. Schluter, editors. Species diversity in ecological communities. University of Chicago Press, Chicago, Illinois, USA.

Latham, R. E., and R. E. Ricklefs. 1993b. Global patterns of tree species richness in moist forests: energy-diversity theory does not account for variation in species richness. Oikos 67:325-333.

Lawton, J. H. 1999. Are there general laws in ecology? Oikos 84:177-192.

Lid, J. 1987. Norsk, svensk, finsk flora. Second edition. Det Norske Samlaget, Oslo, Norway.

Ligon, F. K., W. E. Dietrich, and W. J. Trush. 1995. Downstream ecological effects of dams. BioScience 45:183-192.

Lonsdale, W. M. 1999. Global patterns of plant invasions and the concept of invasibility. Ecology 80:1522-1536.

Manne, L. L., T. M. Brooks, and S. L. Pimm. 1999. Relative risk of extinction of passerine birds on continents and islands. Nature 399:258-261.

Mascher, J. W. 1990. Ångermanlands flora. SBT-förlaget, Lund, Sweden.

Moss, E. H. 1983. Flora of Alberta. University of Toronto Press, Toronto, Canada.

Mossberg, B., L. Stenberg, and S. Ericsson. 1992. Den nordiska floran. Wahlström and Widstrand, Stockholm, Sweden.

Naiman, R. J., R. E. Bilby, and P. A. Bisson. 2000. Riparian ecology and management in the Pacific coastal rain forest. BioScience 50:996-1011.

Naiman, R. J., and H. Décamps. 1997. The ecology of interfaces: riparian zones. Annual Review of Ecology and Systematics 28:621-658.

Naiman, R. J., J. J. Magnuson, D. M. McKnight, and J. A. Stanford. 1995. The freshwater imperative: a research agenda. Island Press, Washington, D.C., USA.

Nekola, J. C., and P. S. White. 1999. The distance decay of similarity in biogeography and ecology. Journal of Biogeography 26:867-878.

Nilsson, C. 1992. Increasing the reliability of vegetation analyses by using a team of two investigators. Journal of Vegetation Science 3:565.

Nilsson, C., A. Ekblad, M. Gardfjell, and B. Carlberg. 1991. Long-term effects of river regulation on river margin vegetation. Journal of Applied Ecology 28:963-987.

Nilsson, C., G. Grelsson, M. Johansson, and U. Sperens. 1989. Patterns of plant species richness along riverbanks. Ecology 70:77-84.

Nilsson, C., R. Jansson, and U. Zinko. 1997. Long-term responses of river-margin vegetation to water-level regulation. Science 276:798-800.

Nilsson, C., and P. A. Keddy. 1988. Predictability of change in shoreline vegetation in a hydroelectric reservoir, northern Sweden. Canadian Journal of Fisheries and Aquatic Sciences 45:1896-1904.

Nilsson, C., E. Nilsson, M. E. Johansson, M. Dynesius, G. Grelsson, S. Xiong, R. Jansson, and M. Danvind. 1993. Processes structuring riparian vegetation. Pages 419-431 in J. Menon, editor. Current topics in botanical research. Council for Scientific Integration, Trivandrum, India.

Nilsson, C., and M. Svedmark. 2002. Basic principles and ecological consequences of changing water regimes: riparian plant communities. Environmental Management 30: 468-480.

Orians, G. H. 1987. Ecological comparisons. Science 235: 226-227.

Orians, G. H., and R. T. Paine. 1983. Convergent evolution at the community level. Pages 431-458 in D. J. Futuyma and M. Slatkin, editors. Coevolution. Sinauer Associates, Sunderland, Massachusetts, USA.
PASS. 1997. PASS version 6.0. NCSS Statistical Software, Kaysville, Utah, USA.

Patten, D. T. 1998. Riparian ecosystems of semi-arid North America: diversity and human impacts. Wetlands 18:498512.

Petts, G. E. 1984. Impounded rivers: perspectives for ecological management. John Wiley and Sons, Chichester, UK. Planty-Tabacchi, A. M., E. Tabacchi, R. J. Naiman, C. DeFerrari, and H. Décamps. 1996. Invasibility of species rich communities in riparian zones. Conservation Biology 10:598-607.

Poff, N. L., J. D. Allan, M. B. Bain, J. R. Karr, K. L. Prestegaard, B. D. Richter, R. E. Sparks, and J. C. Stromberg. 1997. The natural flow regime. BioScience 47:769-784.

Porter, S. C. 1989. Some geological implications of average Quaternary glacial conditions. Quaternary Research 32: 245-261.

Postel, S. L., J. I. Morrison, and P. H. Gleick. 1998. Allocating fresh water to aquatic ecosystems: the case of the Colorado River delta. Water International 23:119-125.

Raab, B., and H. Vedin. 1995. Klimat, sjöar och vattendrag. Sveriges Nationalatlas, Stockholm, Sweden.

Richter, B. D., J. V. Baumgartner, R. Wigington, and D. P. Braun. 1997. How much water does a river need? Freshwater Biology 37:231-249.

Ricklefs, R. E. 1987. Community diversity: relative roles of local and regional processes. Science 235:167-171.

Ricklefs, R. E., and R. E. Latham. 1993. Global patterns in mangrove floras. Pages 215-229 in R. E. Ricklefs and D. Schluter, editors. Species diversity in ecological communities. University of Chicago Press, Chicago, Illinois, USA.

Ritchie, J. C. 1987. Postglacial vegetation of Canada. Cambridge University Press, Cambridge, UK.

Rosenberg, D. M. 1986. Resources and development of the Mackenzie system. Pages 517-540 in B. R. Davies and K. F. Walker, editors. The ecology of river systems. W. Junk, Dordrecht, The Netherlands.

Rosenzweig, M. L. 1995. Species diversity in space and time. Cambridge University Press, Cambridge, UK.

Rudberg, S. 1970. Geomorphology. Maps 5 and 6 in M. Lundqvist, editor. National atlas of Sweden. Generalstabens Litografiska Anstalts Förlag, Stockholm, Sweden.

Schluter, D., and R. E. Ricklefs. 1993. Convergence and the regional component of species diversity. Pages 230-240 in R. E. Ricklefs and D. Schluter, editors. Species diversity in ecological communities. University of Chicago Press, Chicago, Illinois, USA.

Schmiegelow, F. K. A., C. S. Machtans, and S. J. Hannon. 1997. Are boreal birds resilient to forest fragmentation? An experimental study of short-term community responses. Ecology 78:1914-1932.

Sokal, R. R., and F. J. Rohlf. 1995. Biometry. W. H. Freeman, New York, New York, USA.

SPSS. 2000. SPSS version 9.0. SPSS, Chicago, Illinois, USA.

Srivastava, D. S. 1999. Using local-regional richness plots to test for species saturation: pitfalls and potentials. Journal of Animal Ecology 68:1-16.

Stanford, J. A., J. V. Ward, W. J. Liss, C. A. Frissell, R. N. Williams, J. A. Lichatowich, and C. C. Coutant. 1996. A general protocol for restoration of regulated rivers. Regulated Rivers: Research and Management 12:391-413.

Stohlgren, T. J., K. A. Bull, Y. Otsuki, C. A. Villa, and M. Lee. 1998. Riparian zones as havens for exotic plant species in the central grasslands. Plant Ecology 138:113-125.

Taylor, J. P., D. B. Wester, and L. M. Smith. 1999. Soil disturbance, flood management, and riparian woody plant establishment in the Rio Grande floodplain. Wetlands 19: 372-382. 
Terborgh, J. W., and J. Faaborg. 1980. Saturation of bird communities in the West Indies. American Naturalist 116 : 178-195.

Vitousek, P. M., H. A. Mooney, J. Lubchenco, and J. L. Melillo. 1997. Human domination of Earth's ecosystems. Science 277:494-499.

Walter, H. 1985. Vegetation of the earth and ecological systems of the geo-biosphere. Springer-Verlag, Berlin, Germany.

Watts, W. A. 1988. Europe. Pages 155-192 in B. Huntley and T. Webb III, editors. Vegetation history. Kluwer Academic, Dordrecht, The Netherlands.

Webb, T., and P. J. Bartlein. 1992. Global changes during the last 3 million years-climatic controls and biotic responses. Annual Review of Ecology and Systematics 23:141-173.

Westoby, M. 1993. Biodiversity in Australia compared with other continents. Pages 170-177 in R. E. Ricklefs and D. Schluter, editors. Species diversity in ecological communities. University of Chicago Press, Chicago, Illinois, USA.

Wissmar, R. C., and R. L. Beschta. 1998. Restoration and management of riparian ecosystems: a catchment perspective. Freshwater Biology 40:571-585.

Zobel, M. 1997. The relative role of species pools in determining plant species richness: an alternative explanation of species coexistence? Trends in Ecology and Evolution 12:266-269.

\section{APPENDIX A}

A site description and environmental variables sampled at the riparian study sites in Alberta and British Columbia, Canada, are available in ESA's Electronic Data Archive: Ecological Archives A014-002-A1.

\section{APPENDIX B}

A list of species found at each study site in Alberta and British Columbia, Canada, is available in ESA's Electronic Data Archive: Ecological Archives A014-002-A2.

\section{APPENDIX C}

A site description and environmental variables sampled at the riparian study sites in Northern Sweden are available in ESA's Electronic Data Archive: Ecological Archives A014-002-A3.

\section{APPENDIX D}

A list of species found at each study site along free-flowing rivers in northern Sweden is available in ESA's Electronic Data Archive: Ecological Archives A014-002-A4.

\section{APPENDIX E}

A list of species found at each study site along regulated rivers in northern Sweden is available in ESA's Electronic Data Archive: Ecological Archives A014-002-A5.

\section{APPENDIX F}

A list of species in the native species pools of Alberta, Canada, and northern Sweden is available in ESA's Electroninc Data Archive: Ecological Archives A014-002-A6. 